\title{
Functional diversity of human vaginal APC subsets in directing T-cell responses
}

\author{
D Duluc $^{1}, \mathrm{~J} \mathrm{Gannevat}^{1}$, E Anguiano ${ }^{1}, \mathrm{~S}$ Zurawski ${ }^{1}$, M Carley $^{2}$, M Boreham $^{2}$, J Stecher ${ }^{2}$, M Dullaers $^{1}$, \\ $\mathrm{J}_{\text {Banchereau }}{ }^{3}$ and $\mathrm{S} \mathrm{Oh}{ }^{1,4}$
}

Human vaginal mucosa is the major entry site of sexually transmitted pathogens and thus has long been attractive as a site for mounting mucosal immunity. It is also known as a tolerogenic microenvironment. Here, we demonstrate that immune responses in the vagina can be orchestrated by the functional diversity of four major antigen-presenting cell (APC) subsets. Langerhans cells (LCs) and CD14 ${ }^{-}$lamina propria-dendritic cells (LP-DCs) polarize CD4 ${ }^{+}$and CD8 $^{+} \mathrm{T}$

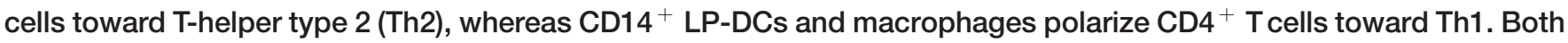
LCs and CD14 ${ }^{-}$LP-DCs are potent inducers of Th22. Owing to their functional specialties and the different expression levels of pattern-recognition receptors on the APC subsets, microbial products do not bias them to elicit common types of immune responses (Th1 or Th2). To evoke desired types of adaptive immune responses in the human vagina, antigens may need to be targeted to proper APC subsets with right adjuvants.

\section{INTRODUCTION}

Female genital tracts, particularly human vaginal mucosa, have long been attractive as a potential site for mounting protective immunity against sexually transmitted pathogens, including viruses and bacteria. ${ }^{1,2}$ However, the vaginal mucosa, a site constantly exposed to foreign antigens, is a unique tolerogenic microenvironment that can control unwanted types of immune responses. ${ }^{1,3-5}$ Nonetheless, the immunology of the human vagina remains poorly understood.

Dendritic cells (DCs) are major antigen-presenting cells (APCs). DCs can direct host immune responses toward either immunity or tolerance. ${ }^{6}$ Subsets of DCs residing in one particular tissue, as well as DCs in draining lymph nodes, have diverse but specialized functions in directing host immune responses. ${ }^{7}$ DCs also display functional plasticity in response to microbial pathogens. ${ }^{8}$ Early studies in animals showed that vaginal mucosa is covered with stratified squamous epithelium $^{2,3,9}$ and shares several common features with the skin. Langerhans cells (LCs), which do not have Birbeck granules, ${ }^{10}$ are found in the epithelium and $\mathrm{CD} 11 \mathrm{c}^{+} \mathrm{DCs}$ in the lamina propria (LP). ${ }^{1,2}$ DC-SIGN ${ }^{+} \mathrm{CCR}^{+}$LP-DCs were also reported in animals. ${ }^{11,12}$ Although the presence of LCs in the human vaginal epithelium has been reported, ${ }^{13}$ no further information is available. Moreover, immunological functions of DCs localized in the human vagina remain unknown.

In this study, we first characterized subsets of DCs and macrophages $(\mathrm{M} \phi)$ that are localized in the human vaginal mucosa by assessing their phenotypes and morphology. We then tested the functional specialties of the individual subsets of APCs in directing $\mathrm{CD}^{+}$and $\mathrm{CD}^{+}{ }^{+}$T-cell responses by measuring the quantity and quality of $\mathrm{T}$-cell responses. We also tested the ability of the individual APC subsets for inducing chemokine receptors that are detected on $\mathrm{T}$ cells in the vaginal mucosa. To address functional plasticity of the vaginal APC subsets, we first assessed the expression levels of Toll-like receptors (TLRs). We were then able to examine T-cell responses induced by the APC subsets activated with different microbial products and their synthetic analogs. Data from this study help us understand how the immune responses in the human vagina are induced and controlled in a steady state, as well as during microbial infections. This study also provides fundamental information for the design of effective mucosal vaccines against many sexually transmitted diseases that still cause a major public health burden worldwide.

${ }^{1}$ Baylor Institute for Immunology Research, Dallas, Texas, USA. ${ }^{2}$ Department of Obstetrics and Gynecology, Baylor University Medical Center, Dallas, Texas, USA. ${ }^{3}$ Pharma Research and Early Development, Hoffmann La Roche, New Jersey, USA and ${ }^{4}$ INSERM U955, Dallas, Texas, USA. Correspondence: S Oh (sangkono@baylorhealth.edu) 


\section{RESULTS}

\section{Human vaginal mucosa contains four major subsets of} myeloid-originated APCs

Mucosal tissues were enzymatically digested and stained with 7 -aminoactinomycin $\mathrm{D}$ and the indicated antibodies (Abs) (Figure 1a). 7-Aminoactinomycin $\mathrm{D}^{-}$HLA-DR ${ }^{+}$cells were separated into HLA-DR ${ }^{+} \mathrm{CD}_{207}{ }^{+}$(Langerin $^{+}: \mathrm{I}$ ) and HLA$\mathrm{DR}^{+} \mathrm{CD}^{2} 7^{-}$cells. HLA-DR ${ }^{+} \mathrm{CD} 207^{-}$cells were further divided into four subsets based on CD1c and CD14 expression: $\mathrm{CD}_{1}{ }^{+} \mathrm{CD}_{14}{ }^{-}$(II), CD1c ${ }^{+} \mathrm{CD}_{14}{ }^{+}$(III), $\mathrm{CD}_{1}{ }^{-} \mathrm{CD} 14^{+}$ (IV), and CD1c ${ }^{-} \mathrm{CD} 14^{-}$(V). CD207 ${ }^{+}, \mathrm{CD}_{1}{ }^{+} \mathrm{CD} 14^{-}$, and

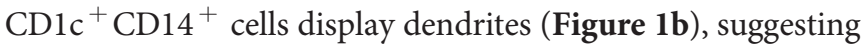
their classification as DCs. $\mathrm{CD} 1 \mathrm{c}^{-} \mathrm{CD} 14^{+}$cells contain large vacuoles in the cytoplasm, which is an $\mathrm{M} \phi$ characteristic. Large fractions of the cells in group V express CD34 (77.41 $\pm 11 \%)$ and CD54 (59.83 $\pm 9.3 \%$ ) (Figure 1c and Supplementary Figure 1a online). Only $6.5 \%$ of them express either CD66 or pan-cytokeratin that are known to be expressed on epithelial cells. E/P selectin is expressed $31 \pm 3.3 \%$ of the cells. The expression levels of CD34, CD54, E/P selectin, and CD123 are higher than those of CD66 and E-cadherin (Supplementary Figure $\mathbf{1 b}$ online). Therefore, the cells in group $\mathrm{V}$ are mainly composed of endothelial cells, but with epithelial cells that can constitutively express major histocompatibility complex class II. ${ }^{14,15}$

$\mathrm{CD}_{207}{ }^{+}$cells are mainly found in the epithelium, whereas the other three subsets $\left(\mathrm{CD} 1 c^{+} \mathrm{CD} 14^{-}, \mathrm{CD} 1 \mathrm{c}^{+} \mathrm{CD} 14^{+}\right.$, and $\mathrm{CD}_{1} \mathrm{C}^{-} \mathrm{CD} 14^{+}$) are in the LP (Figure 1d and Supplementary Figure $2 \mathrm{a}$ online). The percentage of $\mathrm{HLA}-\mathrm{DR}^{+}$cells in total tissues is approximately $10 \%$ (Supplementary Table 1 online). Of the HLA-DR ${ }^{+}$cells, CD1c ${ }^{-} \mathrm{CD} 14^{+}$cells are the most abundant. The frequencies of plasmacytoid DCs, B cells, and $\mathrm{BDCA}^{+}$cells were low. Taken together, human vaginal mucosa contains four major subsets of myeloid-originated APCs: $\mathrm{CD}_{207}{ }^{+}, \mathrm{CD}_{1}{ }^{+} \mathrm{CD} 14^{-}, \mathrm{CD}^{+}{ }^{+} \mathrm{CD} 14^{+}$, and

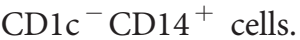

\section{Subsets of the vaginal APCs display shared and distinct surface phenotypes}

The four APC subsets were further characterized by examining their phenotypes (Figure 1e). CD207 ${ }^{+}$cells express both CD1a and E-cadherin, which is expressed on LCs. ${ }^{16} \mathrm{LCs}$, as well as the $\mathrm{CD}_{10}{ }^{+} \mathrm{CD} 14^{-}$LP-DCs (CD14 ${ }^{-}$LP-DCs) and $\mathrm{CD} 1 \mathrm{c}^{+}$
CD14 ${ }^{+}$LP-DCs (CD14 ${ }^{+}$LP-DCs), express both CD86 and CD83. CD1c ${ }^{-} \mathrm{CD}_{14}{ }^{+}$cells express CD86, but not CD83. In addition, $\mathrm{CD} 1 \mathrm{c}^{-} \mathrm{CD} 14^{+}$cells express CD163, which is expressed on $\mathrm{M} \phi .{ }^{17}$ Compared with LCs and the other two subsets of LP-DCs, CD1c ${ }^{-}$CD $14^{+}$cells express lower levels of CD11c, which is in accordance with the classification of these cells as $\mathrm{M} \phi$. Accordingly, CD1a was detected by immunofluorescence on LCs in the epithelium and on $\mathrm{CD}_{14}{ }^{-}$and CD14 ${ }^{+}$LP-DCs (Figure 1f (upper panel) and Supplementary Figure 2 b online). CD163 was detected only on $\mathrm{M} \phi$ (Figure 1f (lower panel) and Supplementary Figure $2 \mathrm{c}$ online).

We next tested whether different subsets of the APCs express distinct patterns of chemokine receptors and $\beta 7$-integrin (Figure 1g). CCR2, a homing receptor for monocytes and $\mathrm{M} \phi,{ }^{18}$ is expressed on M $\phi$ but not on the vaginal DCs. CCR5 and CXCR4, coreceptors for HIV, are expressed on LCs as well as on the other three subsets of APCs. ${ }^{19}$ Interestingly, LP-DCs and $\mathrm{M} \phi$ express increased levels of CCR5 and CXCR4 compared with LCs. Both LCs and LP-DCs exhibit similar levels of CCR6 that is also expressed on intestinal DCs. ${ }^{20}$ $\beta 7$-integrin is detected only on LCs and LP-DCs, but not on $\mathrm{M} \phi$. Both CCR4 and CX3CR1 were similarly expressed on the four subsets of APCs. CCR7 and CD103 were not detected on the surface of the vaginal APC subsets (data not shown). Taken together, the four subsets of vaginal APCs express shared and distinct patterns of surface receptors, including costimulatory molecules and chemokine receptors. This suggested that each subset of the APCs might possess common as well as distinct functions in directing the immune responses in the vagina.

\section{Functional specialties of the vaginal APC subsets in directing $\mathrm{CD4}^{+}$T-cell responses}

5,6-Carboxyfluorescein diacetate succinimidyl ester (CFSE)labeled allogeneic naïve $\mathrm{T}$ cells were cocultured for 7 days with different numbers of the APC subsets, and then $\mathrm{CD} 4{ }^{+} \mathrm{T}$-cell proliferation and intracellular cytokine expression were assessed. Vaginal DCs induced greater $\mathrm{CD} 4{ }^{+} \mathrm{T}$-cell proliferation than did M $\phi$ (Figure 2a (left panel)). CD14 ${ }^{-}$LP-DCs and LCs induced similar levels of naïve $\mathrm{CD} 4{ }^{+} \mathrm{T}$-cell proliferation. However, CD14 ${ }^{+}$LP-DCs were less efficient than LCs at inducing $\mathrm{CD} 4{ }^{+} \mathrm{T}$-cell proliferation. The level of CD4 ${ }^{+} \mathrm{T}$-cell proliferation induced by monocyte-derived dendritic cells (DCs) generated in the presence of IFN $\alpha$ (IFNDCs) $\left(2 \times 10^{3}\right)$

Figure 1 Human vaginal mucosa contains four major subsets of myeloid-originated antigen-presenting cells (APCs). (a) Flow cytometry analysis of cells in human vaginal mucosa after enzymatic digestion. (Left panel) Live HLA-DR ${ }^{+}$cells were gated and (middle panel) $\mathrm{CD}^{207}{ }^{+}$cells (I) were gated. HLA-DR ${ }^{+} \mathrm{CD}_{207^{-}}$cells were further divided into four groups based on CD1c and CD14 expression (right panel: II, CD1c ${ }^{+}$CD14 ${ }^{-}$; III, CD1c ${ }^{+}$CD14 ${ }^{+}$; IV, $\left.\mathrm{CD}_{1 \mathrm{c}^{-}} \mathrm{CD}_{14}^{+} ; \mathrm{V}, \mathrm{CD} \mathrm{c}^{-} \mathrm{CD} 14^{-}\right)$. Data are representative of 20 independent experiments. (b) Morphology of FACS-sorted subpopulations of vaginal cells (original magnification, $\times 100$; bars $=20 \mu \mathrm{m}$ ). Data are representative of four independent experiments. (c) FACS-sorted HLA-DR ${ }^{+}$

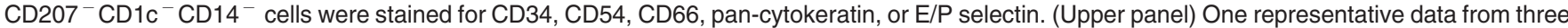
independent experiments using cells from different donors. (Lower panel) Percentage of positive cells has been calculated. Each dot represents data acquired from one donor. (d) Frozen tissue sections were stained for CD207 (green), CD14 (red), CD1c (light blue), and cell nuclei (dark blue) (original magnification, $\times 20$; bar $=100 \mu \mathrm{m}$ ). Data are representative of six independent experiments. $(\mathbf{e}, \mathbf{g})$ Flow cytometry analysis of the vaginal APC subsets. Tissues were digested with enzymes and cell suspension was stained with indicated antibodies and gated as in a. Gray histograms represent isotype controls. Data are representative of $(\mathbf{e}) 10$ or $(\mathbf{g}) 6$ independent experiments. (f) Frozen tissue sections were stained for (upper panel) CD1a (green), CD1c (light blue), and CD14 (red) and (lower panel) CD163, (green), CD1c (light blue), and CD14 (red) (original magnification, $\times 20$; $\mathrm{bar}=100 \mu \mathrm{m})$. Data are representative of six independent experiments. All of the independent experiments were performed with tissues or cells from different donors. DC, dendritic cells; FACS, fluorescence-activated cell sorting; LC, Langerhans cells; LP, lamina propria. 


\section{ARTICLES}
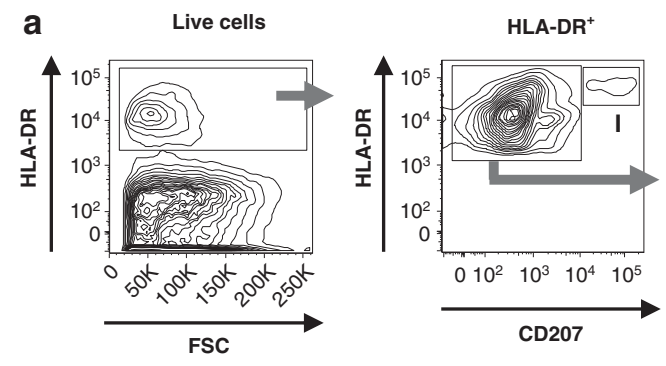

b
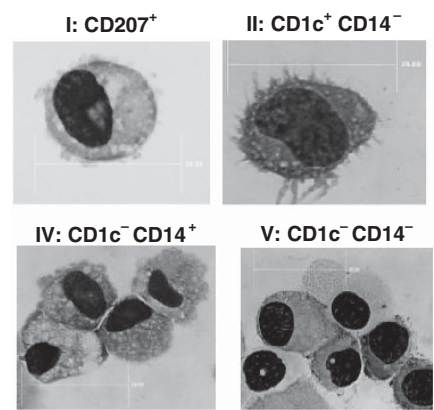

III: $\mathrm{CD} 1 \mathrm{c}^{+} \mathrm{CD} 14^{+}$
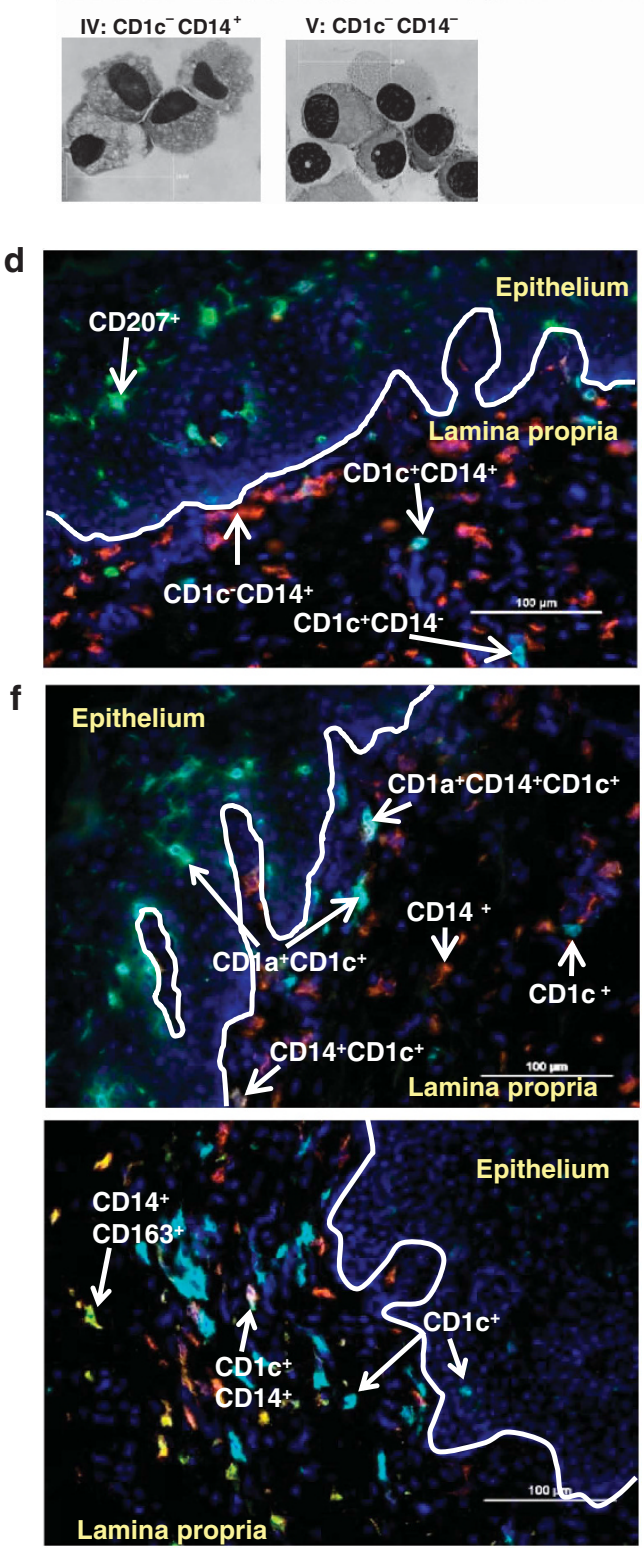

Figure 1 For caption please refer page 627.
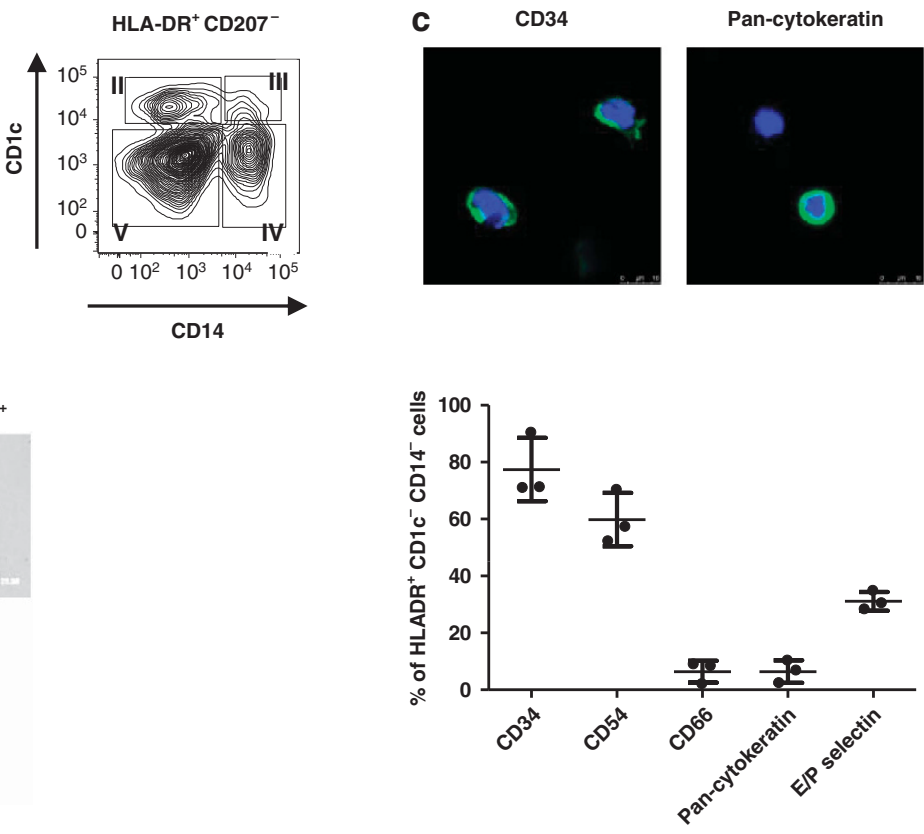

e
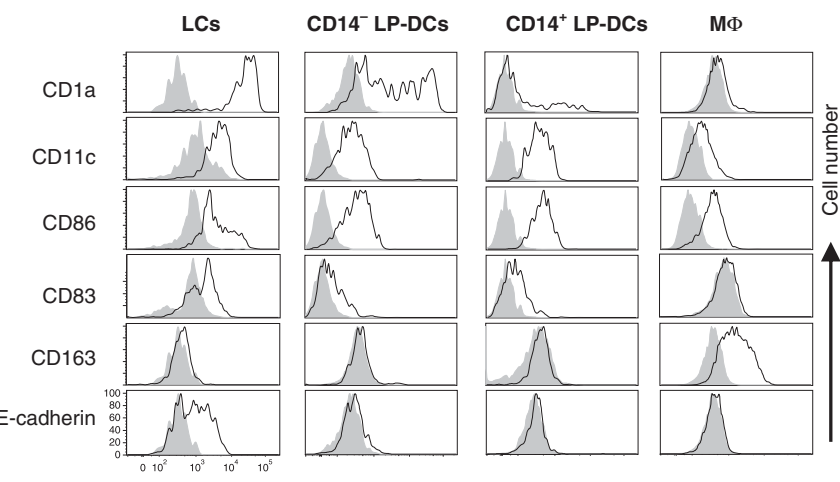

g

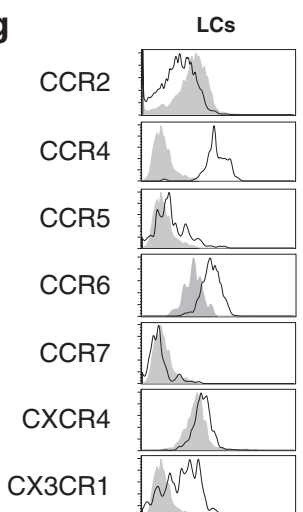

$\beta 7$-Integrin
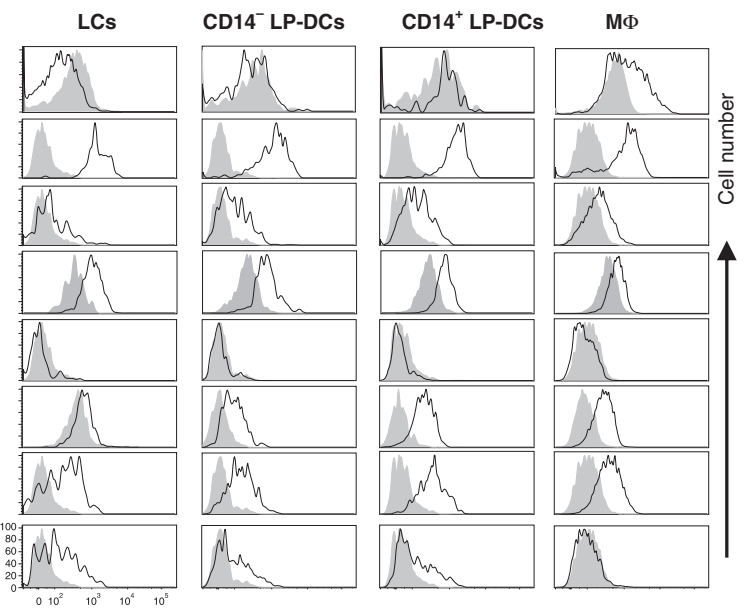

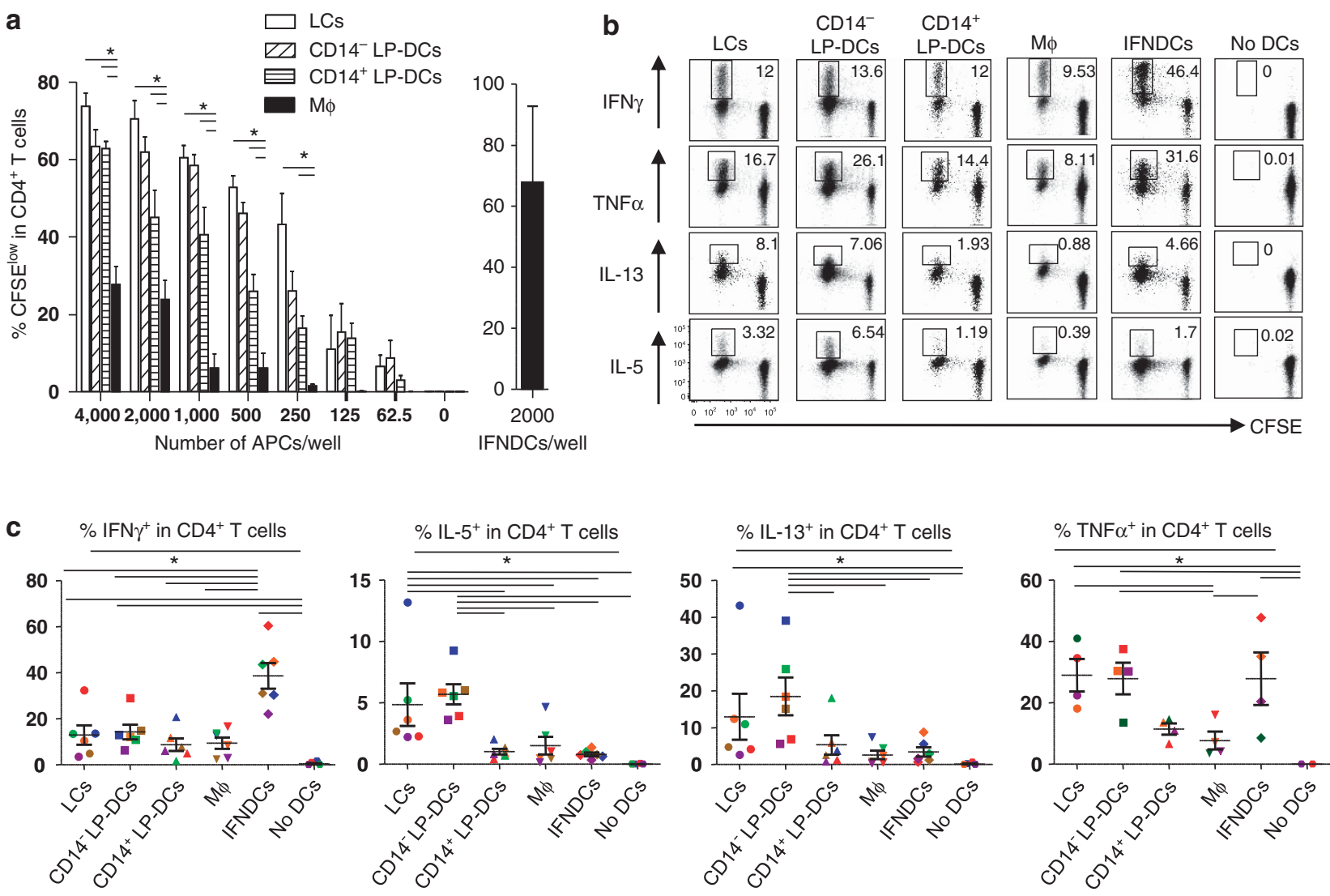

d
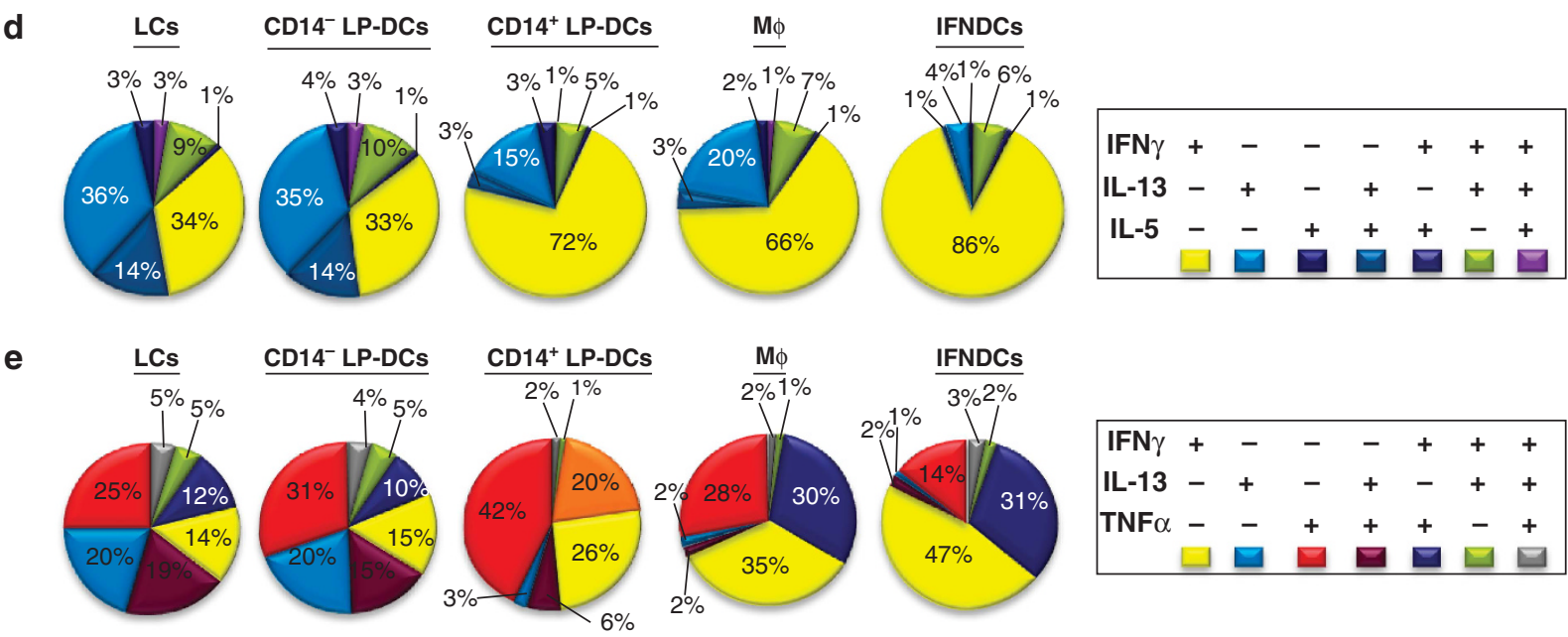

Figure 2 Functional specialties of the vaginal antigen-presenting cell (APC) subsets in directing CD4 ${ }^{+}$T-cell responses. 5,6-Carboxyfluorescein diacetate succinimidyl ester (CFSE)-labeled allogeneic naïve total T cells were cocultured for 7 days with different numbers of the vaginal APCs or dendritic cells (DCs) generated in the presence of interferon (IFN) $\alpha$ (IFNDCs). (a) Live CD4 ${ }^{+} \mathrm{T}_{\text {cells were gated and CD4 }}^{+} \mathrm{T}$-cell proliferation was assessed by measuring CFSE dilution. Data are mean \pm s.d. of three independent experiments with duplicates. (b) After 7 days, T cells were stimulated with phorbol 12-myristate 13-acetate (PMA)/ionomycin in the presence of brefeldin A. Cells were then stained for intracellular IFN $\gamma$, interleukin (IL)-13, IL-5, and tumor necrosis factor- $\alpha(\mathrm{TNF} \alpha)$. Six independent experiments using cells from different donors showed similar data. (c) Summary of the data from independent experiments using APCs from six donors marked with different colors. (d and e) Boolean gate analysis. (d) IFN $\gamma^{+}$, IL-13 ${ }^{+}$, and IL- $5^{+} \mathrm{CD} 4{ }^{+} \mathrm{T}$ cells $(N=6)$ and $(\mathbf{e}) \mathrm{IFN} \gamma^{+}, \mathrm{IL}-13^{+}$, and TNF $\alpha^{+} \mathrm{CD} 4^{+} \mathrm{T}$ cells induced with different subsets of $\mathrm{APCs}(N=3) .{ }^{*} P<0.05$ by analysis of variance (ANOVA) test. LC, Langerhans cells; LP, lamina propria; M $\phi$ macrophages.

was similar to those induced by LCs or CD14- ${ }^{-}$LP-DCs (Figure 2a (right panel)).

All four subsets of the vaginal APCs induced similar percentages of IFN $\gamma^{+} \mathrm{CD} 4^{+}$T cells, ranging from $8.7 \pm 6$ to $14.7 \pm 7 \%$ of total $\mathrm{CD}^{+} \mathrm{T}$ cells (Figure $\mathbf{2 b}$ and Supplementary Figure 3 online). Data generated with cells from different donors are summarized in Figure 2c. Notably, LCs and $\mathrm{CD} 14^{-}$LP-DCs induced greater numbers of $\mathrm{CD} 4^{+}$ 
T cells expressing T-helper type 2 (Th2)-type cytokines as well as tumor necrosis factor (TNF) $\alpha$ than did CD14 ${ }^{+}$LP-DCs and M $\phi$. Although Th17 contribute to the protective immunity against mucocutaneous candidiasis ${ }^{21-23}$ and skin dermal-DCs are potent Th17 inducers, ${ }^{24}$ none of the vaginal APC subsets induced significant levels of interleukin (IL)- $17^{+} \mathrm{CD} 4^{+}$T-cell responses (Supplementary Figure $\mathbf{4 a}$ online). The three vaginal DC subsets displayed similar ability to induce IL$21^{+} \mathrm{CD} 4{ }^{+}$T-cell responses (Supplementary Figure $4 \mathbf{b}$ online), whereas $\mathrm{CD}^{+} 4^{+}$skin dermal-DCs were potent inducers of $\mathrm{IL}-21^{+} \mathrm{CD} 4{ }^{+} \mathrm{T}$ cells. ${ }^{25}$ Furthermore, vaginal LCs and CD $14^{-}$LP-DCs induced similar levels of naïve CD4 ${ }^{+}$ T-cell proliferation, whereas skin LCs were superior to CD1c ${ }^{+}$ dermal-DCs at inducing naïve $\mathrm{CD} 4{ }^{+} \mathrm{T}$-cell proliferation. ${ }^{25}$

The quality of $\mathrm{CD} 4^{+} \mathrm{T}$ cells induced by the vaginal APC subsets was further analyzed by the Boolean gating strategy. LCs and CD14 ${ }^{-}$LP-DCs were able to polarize naïve CD $4^{+} \mathrm{T}$ cells mainly toward Th2, whereas CD14 ${ }^{+}$LP-DCs and M $\phi$ polarized them toward Th1 (Figure 2d). In all, $62 \%$ and $21 \%$ of the LC-induced CD4 ${ }^{+} \mathrm{T}$ cells expressed IL-13 (IL-13 ${ }^{+}$, IL$13^{+} \mathrm{IL}-5^{+}, \mathrm{IL}-13^{+} \mathrm{IFN} \gamma^{+}$, and IL- $\left.13^{+} \mathrm{IFN} \gamma^{+} \mathrm{IL}-5^{+}\right)$and IL$5\left(\mathrm{IL}-5^{+}, \mathrm{IL}-5^{+} \mathrm{IL}-13^{+}, \mathrm{IL}-5^{+}\right.$IFN $\gamma^{+}, \mathrm{IL}-5^{+}$IFN $\left.\gamma^{+} \mathrm{IL}-13^{+}\right)$, respectively. Similarly, $62 \%$ and $22 \%$ of the CD14 ${ }^{-}$LP-DCinduced $\mathrm{CD} 4{ }^{+} \mathrm{T}$ cells expressed IL-13 and IL-5, respectively. In contrast, $79 \%$ and $75 \%$ of the $\mathrm{CD} 4^{+} \mathrm{T}$ cells induced by $\mathrm{CD} 14^{+}$LP-DCs and $\mathrm{M} \phi$, respectively, expressed IFN $\gamma$ $\left(\mathrm{IFN} \gamma^{+}, \quad\right.$ IFN $\gamma^{+} \mathrm{IL}-5^{+}, \quad$ IFN $\gamma^{+} \mathrm{IL}-13^{+}$, and IFN $\gamma^{+} \mathrm{IL}-$ $\left.5^{+} \mathrm{IL}-13^{+}\right)$. Large fractions of $\mathrm{IFN} \gamma^{+} \mathrm{CD} 4^{+} \mathrm{T}$ cells induced with LCs and CD14 $4^{-}$LP-DCs expressed Th2 cytokines, whereas the majority of IFN $\gamma^{+} \mathrm{CD} 4{ }^{+} \mathrm{T}$ cells induced with $\mathrm{CD} 14^{+}$LP-DCs and M $\phi$ did not express IL- 5 or IL-13. The percentage of TNF $\alpha$ single ${ }^{+}$cells induced with LCs (25\%), CD14 ${ }^{-}$LP-DCs (31\%), and M $\phi$ (28\%) were comparable (Figure 2e). However, CD14 ${ }^{+}$LP-DCs resulted in increased percentage of TNF $\alpha$ single ${ }^{+} \mathrm{CD} 4{ }^{+} \mathrm{T}$ cells (42\%). LCs (19\%) and CD14- LP-DCs (15\%) also induced greater percentage of $\mathrm{TNF} \alpha^{+} \mathrm{IL}-13^{+} \mathrm{CD} 4{ }^{+} \mathrm{T}$ cells than $\mathrm{CD} 14^{+} \mathrm{LP}-$ DCs $(6 \%)$ and M $\phi(2 \%)$ did, whereas CD14 ${ }^{+}$LP-DCs $(20 \%)$ and $\mathrm{M} \phi(30 \%)$ induced greater percentage of TNF $\alpha^{+} \mathrm{IFN} \gamma^{+}$ $\mathrm{CD}^{+}{ }^{+} \mathrm{T}$ cells than LCs $(12 \%)$ and CD14 $4^{-}$LP-DCs (10\%) did.

Taken together, both LCs and CD14 ${ }^{-}$LP-DCs polarize naïve $\mathrm{CD} 4{ }^{+} \mathrm{T}$ cells towards Th2, whereas $\mathrm{CD} 14^{+} \mathrm{LP}$-DCs and $\mathrm{M} \phi$ polarize them toward Th1. Furthermore, $\mathrm{CD} 14^{+} \mathrm{LP}-\mathrm{DCs}$ and $\mathrm{M} \phi$ were more efficient than LCs and $\mathrm{CD} 14^{-}$LP-DCs at eliciting $\mathrm{TNF} \alpha$ single $^{+}$as well as $\mathrm{TNF} \alpha^{+} \mathrm{IFN}{ }^{+} \mathrm{CD} 4^{+} \mathrm{T}$-cell responses.

\section{Functional specialties of the vaginal APC subsets in directing $\mathrm{CDB}^{+} \mathrm{T}$-cell responses}

$\mathrm{CD}^{+}{ }^{+}$T-cell responses induced by the vaginal APC subsets were assessed (Figure 3). Compared with $\mathrm{M} \phi$, both LCs and LP-DCs induced enhanced $\mathrm{CD}^{+}{ }^{+} \mathrm{T}$-cell proliferation (Figure 3a). Notably, the three vaginal DC subsets were equally potent at inducing naive $\mathrm{CD} 8^{+}$T-cell proliferation, although human skin LCs were superior to dermal-DCs at eliciting CD8 ${ }^{+}$T-cell proliferation. $^{25}$
Both LCs and CD14 ${ }^{-}$LP-DCs showed similar ability to induce IFN $\gamma^{+}$and $\mathrm{TNF}^{+}{ }^{+} \mathrm{CD} 8{ }^{+} \mathrm{T}$-cell responses (Figure $3 \mathbf{b}$ and Supplementary Figure 5 online). However, LCs and CD14 ${ }^{-}$LP-DCs were more efficient than $\mathrm{M} \phi$ and $\mathrm{CD} 14^{+} \mathrm{LP}-$ DCs at inducing $\mathrm{IFN} \gamma^{+}$and $\mathrm{TNF} \alpha^{+} \mathrm{CD} 8^{+} \mathrm{T}$-cell responses. Increased numbers of $\mathrm{CD}^{+}{ }^{+} \mathrm{T}$ cells induced with LCs and CD14- ${ }^{-}$LP-DCs expressed IL-5, but not IL-13 (data not shown). Data from six (IFN $\gamma$ and IL-5) and three (TNF $\alpha$ ) independent experiments are summarized in Figure $3 \mathbf{c}$. The vaginal APC subsets did not induce significant numbers of IL$21^{+}$or $\mathrm{IL}-17^{+} \mathrm{CD} 8^{+} \mathrm{T}$ cells (data not shown). Figure 3d further demonstrates that large fractions of $\mathrm{IFN}^{+} \mathrm{CD} 8^{+}$ $\mathrm{T}$ cells induced by LCs and CD14- ${ }^{-}$LP-DCs express IL- 5 . The increased percentages of IFN $\gamma^{+} \mathrm{CD} 8^{+} \mathrm{T}$ cells by LCs and $\mathrm{CD} 14^{-}$LP-DCs were mainly due to the increased induction of IFN $\gamma^{+} \mathrm{TNF}^{-} \mathrm{CD} 8{ }^{+} \mathrm{T}$ cells, but not IFN $\gamma^{+} \mathrm{TNF} \alpha^{+} \mathrm{CD} 8^{+}$ $\mathrm{T}$ cells (Figure $3 \mathbf{e}$ ).

Taken together, LCs and the two subsets of LP-DCs are equal but more potent than $\mathrm{M} \phi$ at inducing $\mathrm{CD}^{+}{ }^{+} \mathrm{T}$-cell proliferation. Compared with CD14 ${ }^{+}$LP-DCs and M $\phi$, LCs and $\mathrm{CD}_{14}{ }^{-}$LP-DCs can induce increased level of $\mathrm{IL}-5^{+} \mathrm{CD} 8{ }^{+}$T-cell responses.

\section{Common and distinct functions of the vaginal APC subsets in the induction of CD103, $\beta 7$-integrin, and chemokine receptor expression on $\mathrm{T}$ cells}

Expression of CD103, $\beta 7$-integrin, and chemokine receptors on the $\mathrm{T}$ cells in the vaginal was investigated. Fractions of $\mathrm{CD} 4^{+}$ (28.2\%) and $\mathrm{CD} 8{ }^{+} \mathrm{T}$ cells (67.2\%) from the vagina and $\mathrm{T}$ cells in the vaginal mucosa $\left(\mathrm{CD} 4^{+}\right.$in Figure $4 a$ and Supplementary Figure $6 \mathbf{a}$ online and $\mathrm{CD}^{+}$in Figure $4 \mathbf{b}$ and Supplementary Figure $\mathbf{6 b}$ online, and Figure $4 \mathbf{c}$ ) express CD103 that could allow T-cell migration or retention in the vagina. ${ }^{26-29}$ More importantly, vaginal DCs and $M \phi$ in a less extent were able to induce $\mathrm{CD} 103$ on $\mathrm{CD}^{+}{ }^{+}$(upper panels, Figure 4d) and especially $\mathrm{CD} 8^{+} \mathrm{T}$ cells (lower panels, Figure 4d). $\mathrm{CD} 14^{+}$LP-DCs were less efficient than the other two DC subsets, but more efficient than M $\phi$ and IFNDCs at inducing CD103 expression. Fractions of $\mathrm{CD} 4^{+}$and CD8 ${ }^{+}$ $\mathrm{T}$ cells from the vaginal mucosa also expressed CCR4 (Figure 4e). All four subsets of the vaginal APCs were capable of inducing CCR4 expression on $\mathrm{CD}^{+}{ }^{+}$and $\mathrm{CD} 8^{+}$ $\mathrm{T}$ cells (Figure $\mathbf{4 f}$ ). Notably, the majority of $\mathrm{CFSE}^{\text {low }} \mathrm{T}$ cells induced with $\mathrm{M} \phi$ expressed CCR4. Fractions of $\mathrm{CD}^{+}$and $\mathrm{CD}^{+} \mathrm{T}$ cells from the vaginal mucosa also express $\beta 7$-integrin (Supplementary Figure $7 \mathbf{a}$ online) and CXCR3 $3^{30}$ (Supplementary Figure $7 \mathrm{c}$ online). All four subsets of the vaginal APCs were almost equally capable of inducing $\beta 7$-integrin (Supplementary Figure $7 \mathbf{b}$ online) and CXCR3 (Supplementary Figure $\mathbf{7 d}$ online) on $\mathrm{CD}^{+}$(upper panels) and CD8 ${ }^{+} \mathrm{T}$ cells (lower panels). Taken together, $\mathrm{T}$ cells in the vagina express $\mathrm{CD} 103, \beta 7$-integrin, CCR4, $\beta 7$-integrin, and CXCR3. Vaginal APCs can induce these receptors on both $\mathrm{CD}^{+}{ }^{+}$and $\mathrm{CD} 8{ }^{+} \mathrm{T}$ cells, but individual subsets could display common and distinct functions at inducing these receptor expressions on T cells. 
Microbial products can bias the individual APC subsetdriven T-cell responses

RNA expression levels of TLRs, melanoma differentiationassociated gene $5,{ }^{31}$ and retinoic-acid-inducible protein $\mathrm{I}^{32}$ in the four APC subsets were assessed (Figure 5a). Both TLR8 and melanoma differentiation-associated gene 5 were the most universally expressed in the vaginal DCs. LCs expressed higher level of TLR7 than LP-DCs. CD14 ${ }^{+}$LP-DCs expressed TLR6
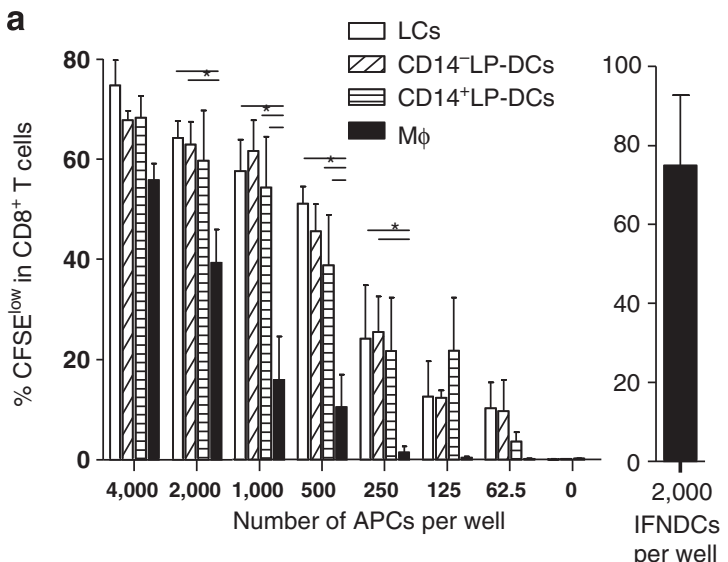

b
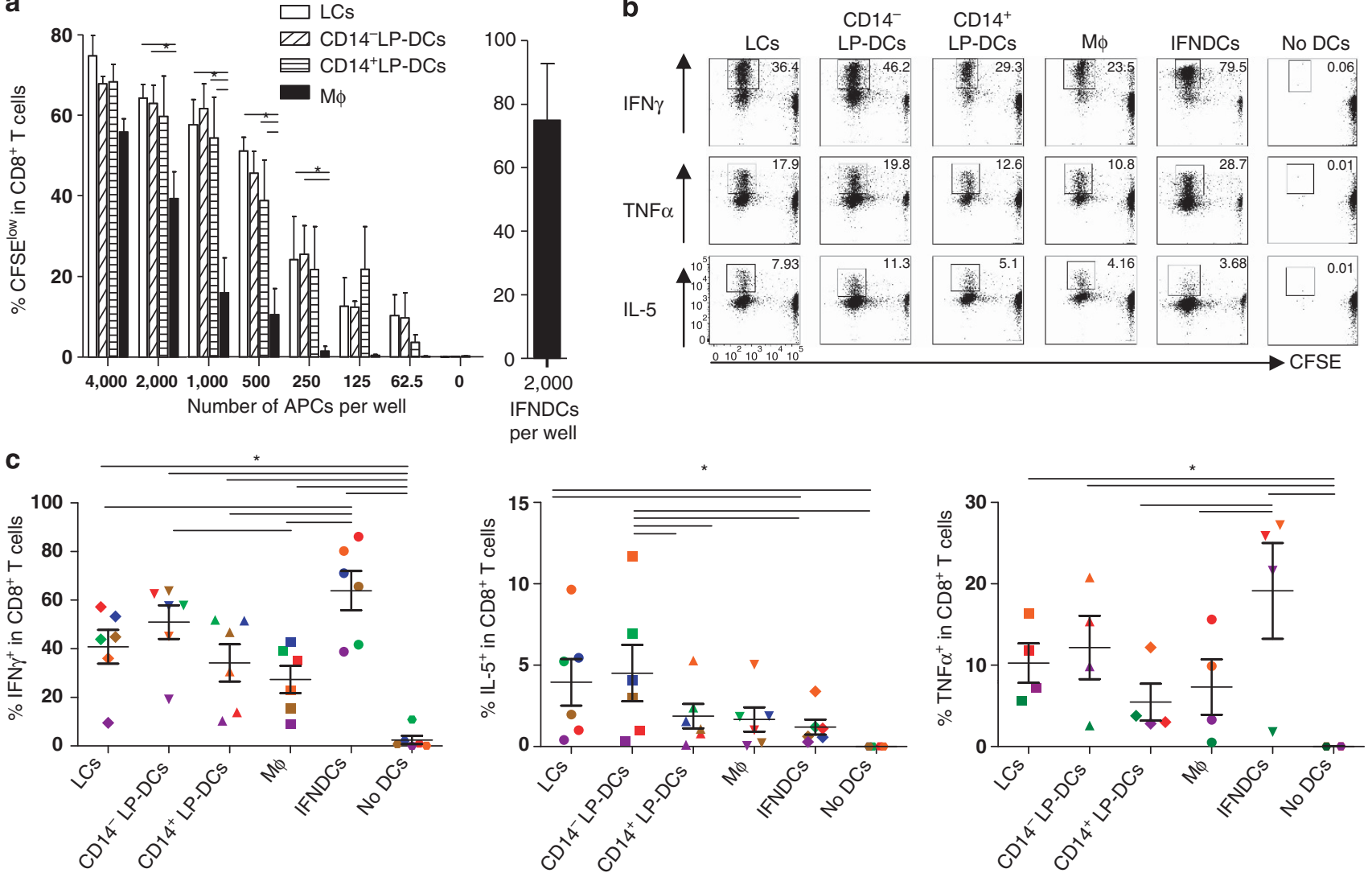

d

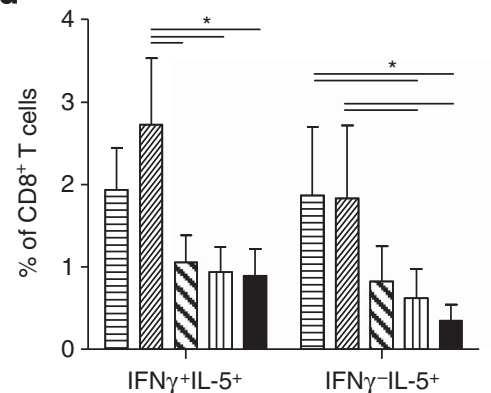

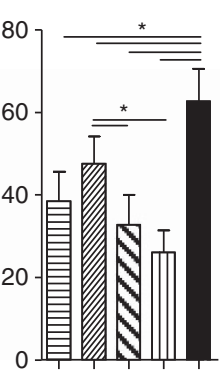

IFN $\gamma^{+}+\mathrm{LL}-5^{-}$ e

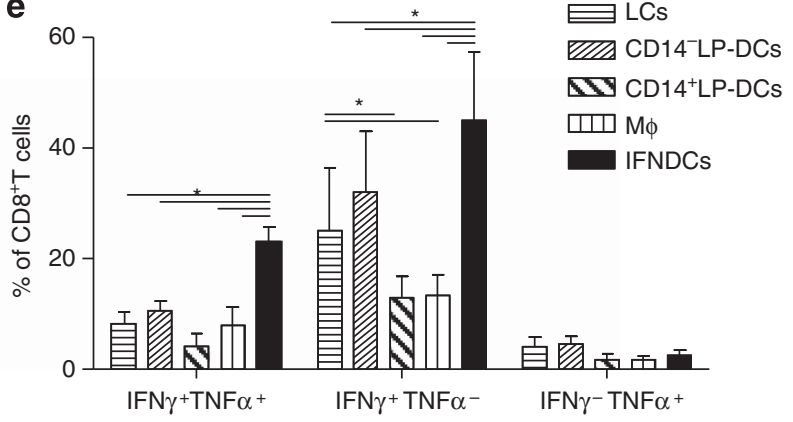

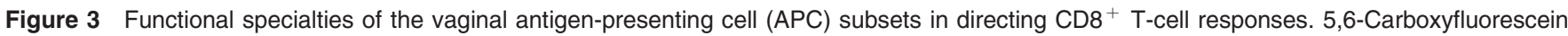
diacetate succinimidyl ester (CFSE)-labeled allogeneic naïve total T cells were cocultured for 7 days with the vaginal APC subsets or dendritic cells (DCs) generated in the presence of interferon (IFN) $\alpha$ (IFNDCs). (a) CD8 ${ }^{+}$T-cell proliferation was assessed by measuring CFSE dilution. Data are mean \pm s.d. of three independent experiments with duplicates. (b-e) After 7 days, T cells were stimulated with phorbol 12-myristate 13-acetate (PMA)/ ionomycin in the presence of brefeldin A, and then stained for intracellular IFN $\gamma$, tumor necrosis factor- $\alpha$ (TNF $\alpha$ ), and interleukin (IL)-5 expression. (b) Representative data of six independent experiments. (c) Summary of the data from six (IFN $\gamma^{+}$and IL-5 $5^{+}$) and four (TNF $\alpha^{+}$) independent experiments using cells from different donors. (d) IFN $\gamma^{+}$and IL- $5^{+} \mathrm{CD} 8^{+} \mathrm{T}$ cells $(N=6)$ or $(\mathbf{e})$ IFN $\gamma^{+}$and TNF $\alpha^{+} \mathrm{CD} 8^{+} \mathrm{T}$ cells induced with different APC subsets $(N=3)$. ${ }^{*} P<0.05$ by analysis of variance (ANOVA) test. LC, Langerhans cells; LP, lamina propria; M $\phi$, macrophages.

Figure 4 Vaginal antigen-presenting cells (APCs) can induce naïve T cells to express CD103 and CCR4 that are found to be expressed in T cells in the vaginal mucosa. (a) Frozen tissue sections were stained for CD3, CD4, and CD103 and (b) CD3, CD8, and CD103 expression (original magnification, $\times 20$; bar $=100 \mu \mathrm{m}$ ). (c) CD103 and (e) CCR4 expressions on (top panel) CD4 ${ }^{+}$and (bottom panel) $\mathrm{CD}^{+}{ }^{+} \mathrm{T}$ cells from the vaginal mucosa. (d) CD103 and (f) CCR4 expressions on naïve 5,6-carboxyfluorescein diacetate succinimidyl ester (CFSE)-labeled (top panels) $\mathrm{CD}^{+}{ }^{+}$and (bottom panels) $\mathrm{CD} 8^{+} \mathrm{T}^{-}$ cells cocultured for 7 days with the vaginal APC subsets or dendritic cells (DCs) generated in the presence of interferon $\alpha$ (IFNDCs). (a-c and $\mathbf{e}$ ) T cells in the vagina from five donors showed similar results. (d and f) Four independent experiments using APCs from different donors showed similar results. DAPI, 4',6-diamidino-2-phenylindole; FITC, fluorescein isothiocyanate; LC, Langerhans cells; LP, lamina propria; M $\phi$, macrophages. 

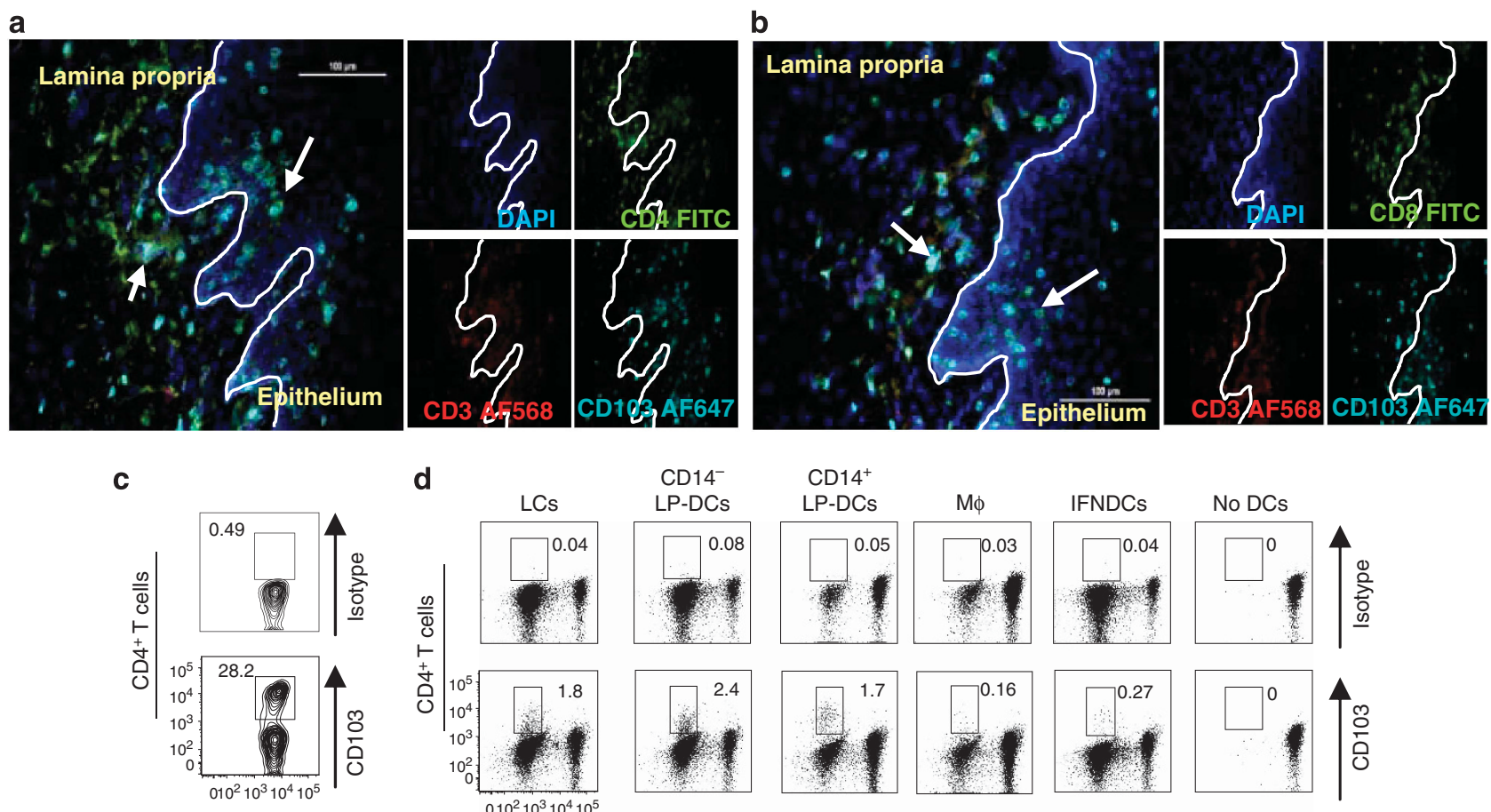

d

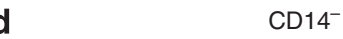

$\mathrm{CD}_{14}^{+}$
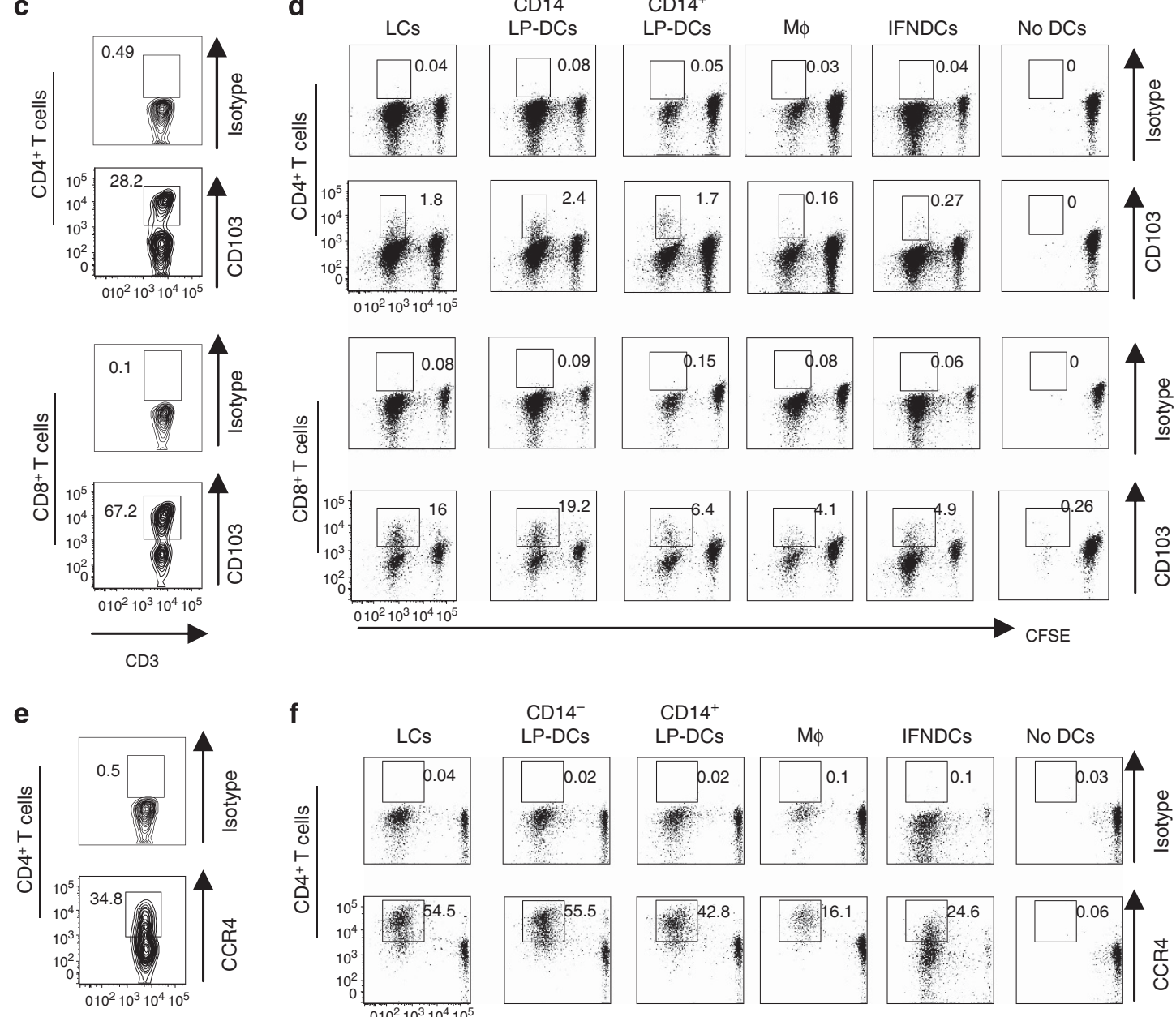

f
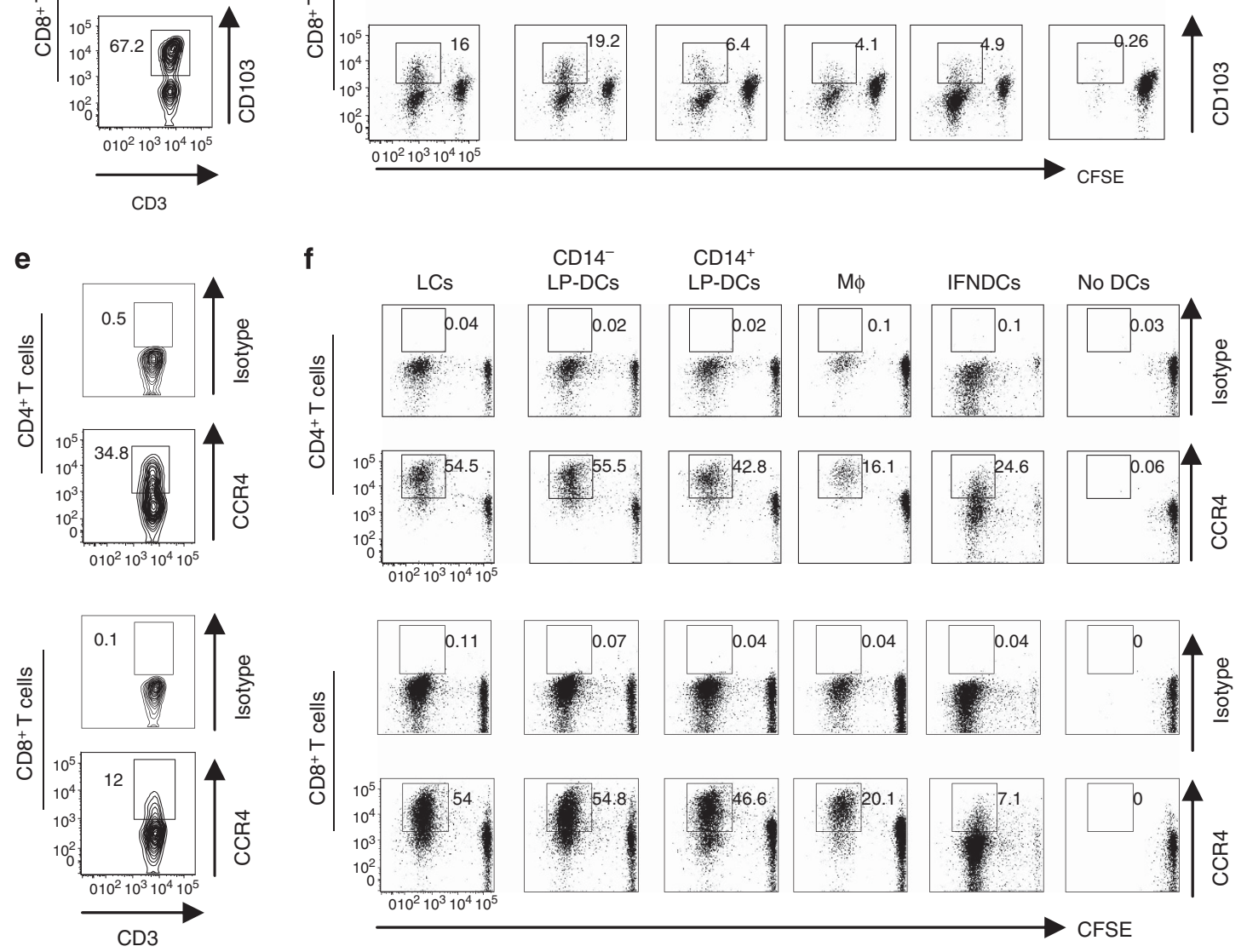

Figure 4 For caption please refer page 631. 
a

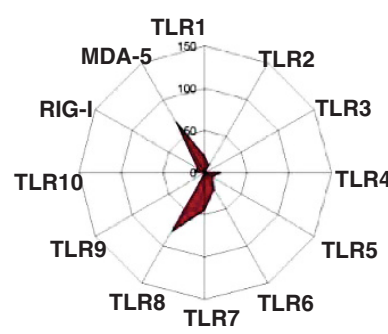

b
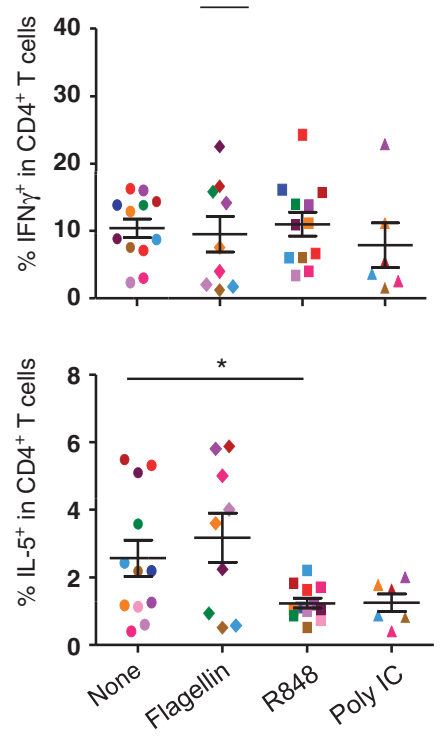

C
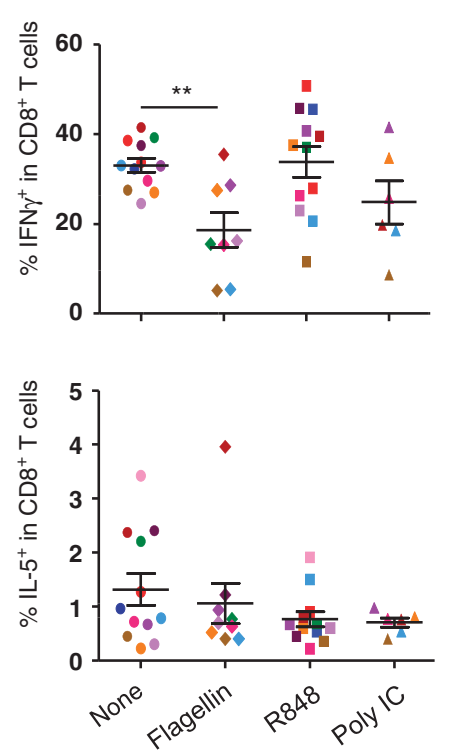

CD14- LP-DCs
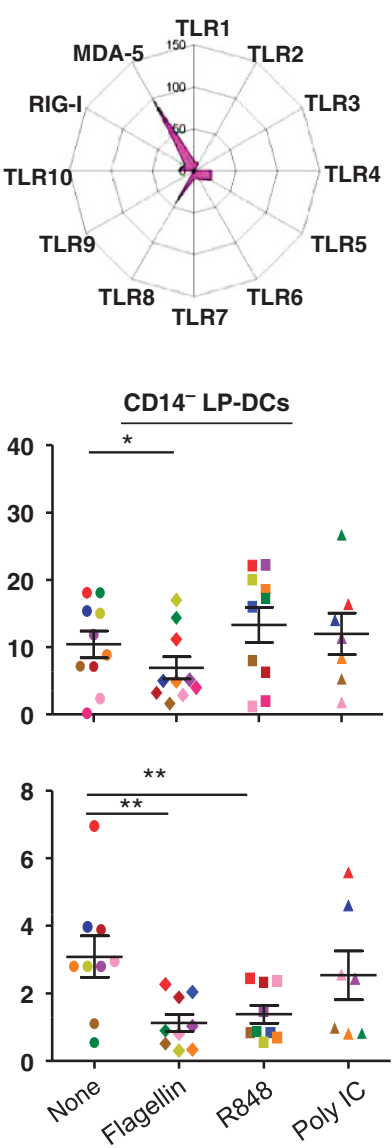

CD14- LP-DCs
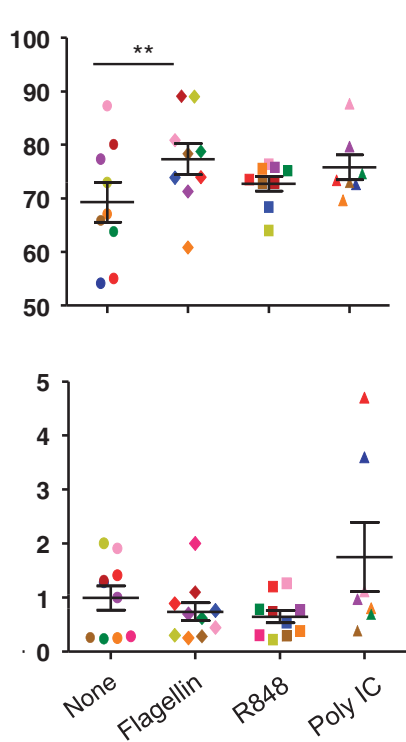
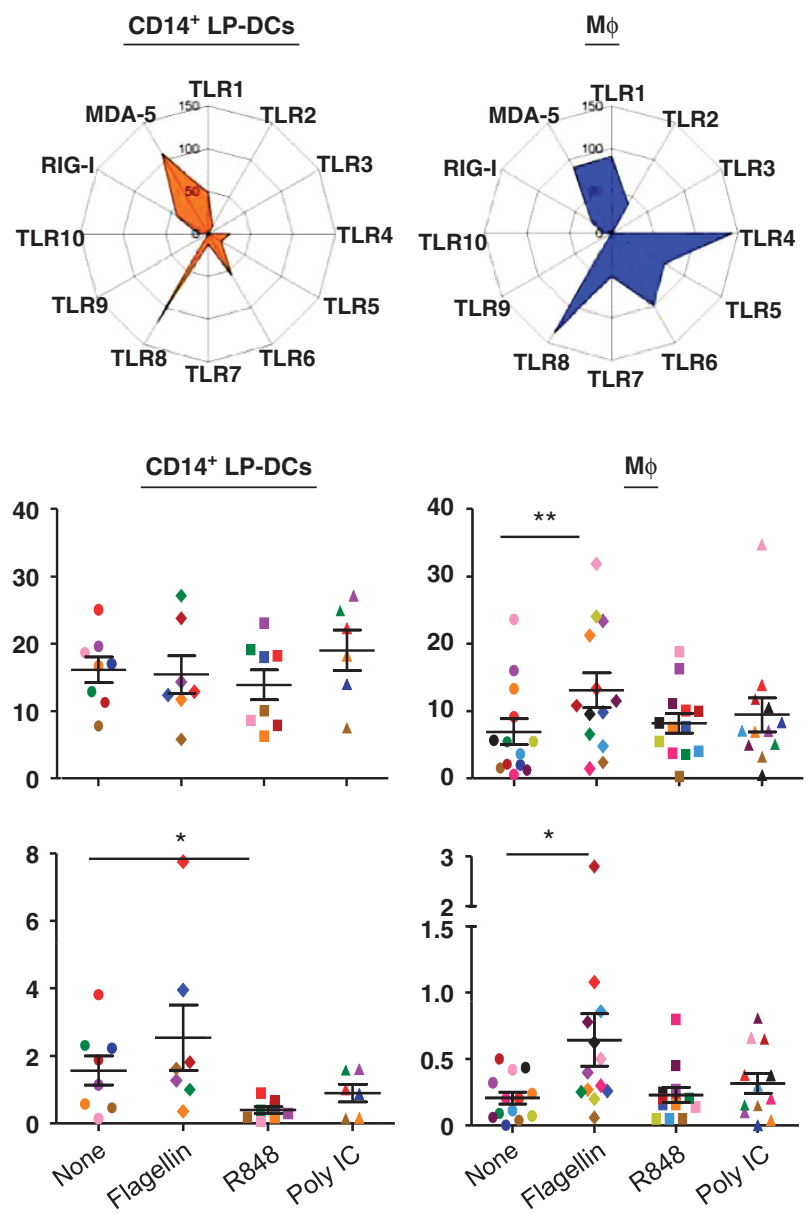

CD14+ LP-DCs
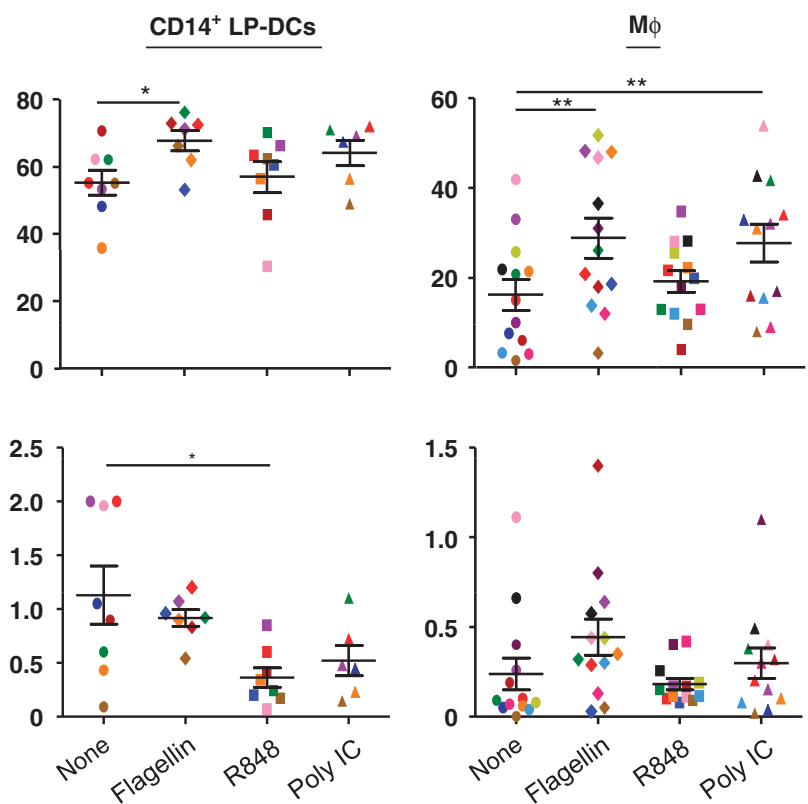

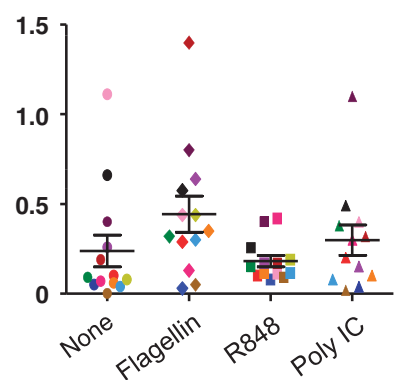

Figure 5 Expression levels of pattern-recognition receptors and their effects on the antigen-presenting cell (APC) subset-driven T-cell responses. (a) Toll-like receptors (TLRs), melanoma differentiation-associated gene 5 (MDA-5), and retinoic-acid-inducible protein I (RIG-I) average gene expression in FACS-sorted vaginal Langerhans cells (LCs) $(N=2)$, CD14 ${ }^{-}$lamina propria-dendritic cells $(\mathrm{LP}-\mathrm{DCs})(N=3), \mathrm{CD} 14^{+} \mathrm{LP}-\mathrm{DC}$ s $(N=2)$, and macrophages $(\mathrm{M} \phi)(N=6)$. (b, c) APC subsets were stimulated with flagellin, R848, or poly-IC for $16 \mathrm{~h}$ and then 5,6-carboxyfluorescein diacetate succinimidyl ester (CFSE)-labeled naïve total T cells were cocultured for 7 days. T cells were stimulated with phorbol 12-myristate 13-acetate (PMA)/ionomycin in the presence of brefeldin $A$ and then stained for intracellular interferon (IFN) $\gamma$ and interleukin (IL)-5 expression. Each color represents the data generated with one tissue donor $\left({ }^{\star} P<0.05\right.$ and ${ }^{* \star} P<0.01$; paired $t$-test). (b) $\mathrm{CD} 4^{+}$and (c) $\mathrm{CD} 8{ }^{+}{ }^{\mathrm{T}}$ cells. FACS, fluorescence-activated cell sorter. 
and retinoic-acid-inducible protein I, which were minimally expressed in LCs and CD14 $4^{-}$LP-DCs. Compared with the three subsets of DCs, M $\phi$ expressed increased levels of TLR1, TLR2, TLR4, and TLR6. It was of note that vaginal DCs express increased levels of TLRs for viral products, whereas $M \phi$ express TLRs for both viral and bacterial products.

We next tested the effects of bacterial flagellin (TLR5 ligand), R848 (ssRNA: TLR7/8 ligand), poly-IC (dsRNA: TLR3, melanoma differentiation-associated gene 5 , and retinoicacid-inducible protein I ligand) and Escherichia coli lipopolysaccharide (E. coli LPS: TLR4 ligand), on the vaginal APCinduced $\mathrm{CD} 4{ }^{+}$T-cell responses (Figure 5b). R848 enhances LC- and CD14 ${ }^{-}$LP-DC-induced CD4 ${ }^{+}$T-cell proliferation (Supplementary Figure 8a online), but decreases IL- ${ }^{+} \mathrm{CD} 4{ }^{+}$ $\mathrm{T}$-cell responses, as reported previously, ${ }^{33}$ without altering IFN $\gamma^{+} \mathrm{CD}^{+}$T-cell responses. Melanoma differentiationassociated gene 5 was universally expressed in the four APC subsets, but the effect of poly-IC was minimal, except for the enhanced $\mathrm{CD} 4{ }^{+} \mathrm{T}$-cell proliferation induced by $\mathrm{CD} 14^{+} \mathrm{LP}$ DCs and $M \phi$ (Supplementary Figure 8a online). Flagellin enhanced $\mathrm{CD} 4{ }^{+}$T-cell proliferation induced by the four APC subsets. Interestingly, however, flagellin-activated CD14 ${ }^{-}$LPDCs decreased both IFN $\gamma^{+} \mathrm{CD} 4{ }^{+}$and $\mathrm{IL}-5^{+} \mathrm{CD} 4{ }^{+}$T-cell responses, whereas flagellin-activated $\mathrm{M} \phi$ enhanced both IFN $\gamma^{+} \mathrm{CD} 4{ }^{+}$and $\mathrm{IL}-5^{+} \mathrm{CD} 4{ }^{+}$T-cell responses.

Both poly-IC and flagellin enhanced $\mathrm{CD} 8^{+}$T-cell proliferation induced by the four APC subsets (Supplementary Figure $\mathbf{8 b}$ online). However, poly-IC did not significantly alter the levels of IFN $\gamma^{+} \mathrm{CD} 8{ }^{+}$or IL- $5^{+} \mathrm{CD} 8{ }^{+}$T-cell responses induced by the DC subsets, but enhanced $M \phi$-induced IFN $\gamma^{+} \mathrm{CD}^{+}$T-cell responses (Figure 5c). TLR4 was highly expressed in $\mathrm{M} \phi$, but $E$. coli LPS did not significantly alter $\mathrm{M} \phi$-induced $\mathrm{IFN} \gamma^{+}$or $\mathrm{IL}-5^{+}$T-cell responses (Supplementary Figure 9 online). It rather promoted LC- and CD14 ${ }^{-}$LP-DC-induced CD4 ${ }^{+}$T-cell proliferation (Supplementary Figure 9a online) and LC- and $\mathrm{CD}^{+} 4^{+}$LP-DC-induced $\mathrm{CD}^{+}{ }^{+}$T-cell proliferation (Supplementary Figure 9b online).

Taken together, individual subsets of the vaginal APCs display their own functional plasticity in directing $\mathrm{CD} 4{ }^{+}$and $\mathrm{CD}^{+}{ }^{-}$-cell responses. None of the stimuli bias the four APC subsets to induce common types of immune responses. Thus, the immune responses, particularly Th1 vs. Th2, in the vagina can be well balanced by distinct but compensatory functions of the individual APC subsets in the vagina.

\section{Both LCs and CD14 ${ }^{-}$LP-DCs are potent inducers of IL-22- producing $\mathrm{CD}^{+}{ }^{+} \mathrm{T}$ cells}

IL-22 induces the secretion of antimicrobial products and contributes to the recovery of epithelial cells. ${ }^{34-37}$ As shown in Figure 6a, both LCs and CD14 ${ }^{-}$LP-DCs display similar ability to induce IL- $22{ }^{+} \mathrm{CD} 4{ }^{+}$T-cell responses, although LCs in human skins are superior to dermal-DCs. ${ }^{38}$ Data from six independent experiments are summarized in Figure $\mathbf{6 b}$. CD14 ${ }^{-}$LP-DC-induced IL-22 ${ }^{+} \mathrm{CD} 4^{+}$T cells were further analyzed for IFN $\gamma$, IL-17, and IL-5 expression (Figure 6c).
Summarized data indicate that the overall quality of $\mathrm{IL}-22^{+} \mathrm{CD} 4{ }^{+} \mathrm{T}$ cells induced with the four APC subsets is similar (Figure 6d), but different from those induced with the control IFNDCs. Compared with the vaginal APCs, IFNDCs induced less numbers of IL-22 single ${ }^{+} \mathrm{CD}^{+} \mathrm{T}$ cells. Approximately $3-5 \%$ of the IL- $22^{+} \mathrm{CD} 4{ }^{+} \mathrm{T}$ cells induced with IFNDCs also expressed IL-17. It was also of note that approximately $40-60 \%$ of the IL- $22{ }^{+} \mathrm{CD} 4{ }^{+} \mathrm{T}$ cells induced by the vaginal APCs expressed IFN $\gamma$. Although the three subsets of vaginal DCs resulted in greater IL-22 ${ }^{+} \mathrm{CD} 8{ }^{+} \mathrm{T}$-cell responses than did $M \phi$ in some experiments, there was no significant difference between the DCs and $\mathrm{M} \phi$ at inducing $\mathrm{IL}-22^{+} \mathrm{CD} 8{ }^{+}$ T-cell responses (Figure 6e). IL- $22^{+} \mathrm{CD}^{+}{ }^{+} \mathrm{T}$ cells induced with the APC subsets displayed similar patterns of IL-5 and IFN $\gamma$ expression, the majority of the IL- $22{ }^{+} \mathrm{CD} 8{ }^{+} \mathrm{T}$ cells also expressed IFN $\gamma$ or IL-5, but not IL-17 (Figure 6f).

We next tested whether microbial products or analogs could alter the vaginal APC-induced IL-22 ${ }^{+}$T-cell responses. Most notably, R848-activated LCs and CD14 ${ }^{-}$LP-DCs, which can enhance $\mathrm{CD} 4{ }^{+}$T-cell proliferation (Supplementary Figure 8a online), enhanced IL-22 ${ }^{+} \mathrm{CD} 4{ }^{+} \mathrm{T}$-cell responses (Figure $6 \mathrm{~g}$ ), but decreased $\mathrm{IL}-5^{+} \mathrm{CD} 4^{+}$T-cell responses (Figure 5b). Flagellin was able to enhance CD14 ${ }^{-} \mathrm{LP}_{-} \mathrm{DC}{ }^{-}, \mathrm{CD} 14^{+} \mathrm{LP}-$ $\mathrm{DC}^{-}$, and $\mathrm{M} \phi$-induced $\mathrm{IL}-22^{+} \mathrm{CD} 4{ }^{+} \mathrm{T}$-cell responses. The effects of these stimuli on the induction of IL- $22{ }^{+} \mathrm{CD} 8{ }^{+} \mathrm{T}$-cell responses were minimal, although flagellin-activated $\mathrm{M} \phi$ enhanced $\mathrm{IL}-22^{+} \mathrm{CD} 8{ }^{+}$T-cell responses (Figure $6 \mathbf{h}$ ). E. coli LPS did not significantly alter the vaginal APCinduced IL-22 ${ }^{+} \mathrm{CD}^{+}{ }^{+}$(Supplementary Figure 10a online) or $\mathrm{IL}-22^{+} \mathrm{CD} 8{ }^{+} \mathrm{T}$-cell responses (Supplementary Figure 10b online).

Taken together, both LCs and CD14 ${ }^{-}$LP-DCs are potent inducers of IL- $22{ }^{+} \mathrm{CD} 4{ }^{+}$T-cell responses that can be further promoted by R848. CD14 ${ }^{+}$LP-DC- and $\mathrm{M} \phi$-induced IL$22^{+} \mathrm{CD} 4{ }^{+}$T-cell responses are promoted by flagellin. The ability of the vaginal DCs to induce increased percentage of both IL- $22^{+}$IFN $\gamma^{+}$and IL- $22^{+}$IL-5 ${ }^{+}$T-cell responses further distinguish them from DCs in skin. ${ }^{38}$

\section{DISCUSSION}

This study demonstrates, for the first time, that human vaginal mucosa harbors four major myeloid-originated APC subsets (LCs, CD14 ${ }^{-}$LP-DCs, CD14 ${ }^{+}$LP-DCs, and M $\phi$ ) that show distinct phenotypes and functions in directing the immune responses in the vaginal mucosa. These APCs are further distinguished from those of other human tissues, including skin $^{24,25,38,39}$ and intestine, ${ }^{40}$ by displaying distinct functions in directing both $\mathrm{CD} 4^{+}$and $\mathrm{CD} 8^{+}$T-cell responses. These characters of the vaginal APCs support a current notion that human vaginal mucosa is an immunologically unique microenvironment that is different from other tissues or organs. ${ }^{1,3,4}$

Th1, Th2, and Th22 are the major types of immune responses induced by the vaginal APCs. They are not potent inducers of IL-10-producing CD4 ${ }^{+} \mathrm{T}$ cells (data not shown) or Th17, which contribute to the protective immunity in the vagina. ${ }^{21-23}$ All three DC subsets are almost equally capable of 
a

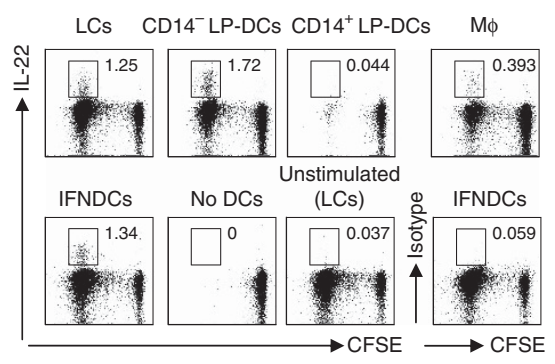

b c

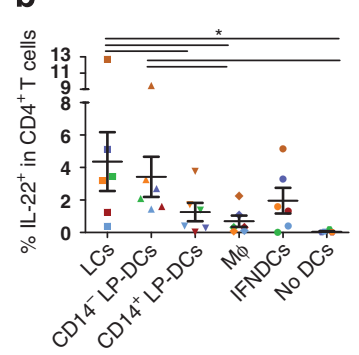

C

Gated on IL-22 ${ }^{+}$cells

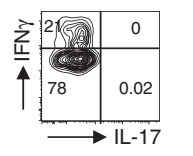

Gated on IL-17 $17^{-}$cells

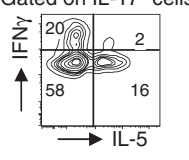

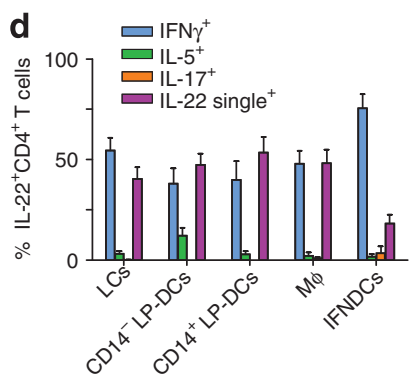
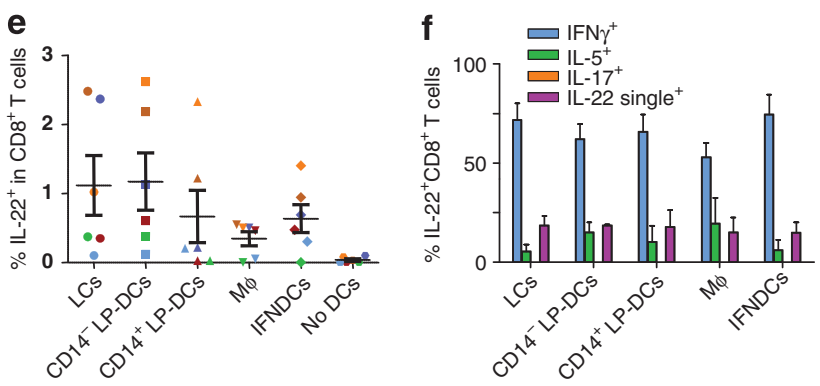

g
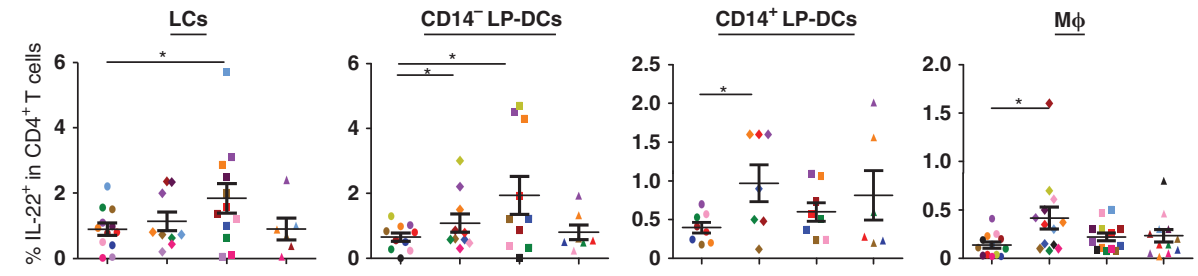

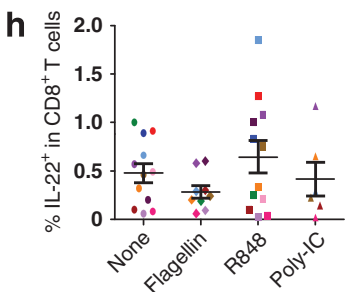
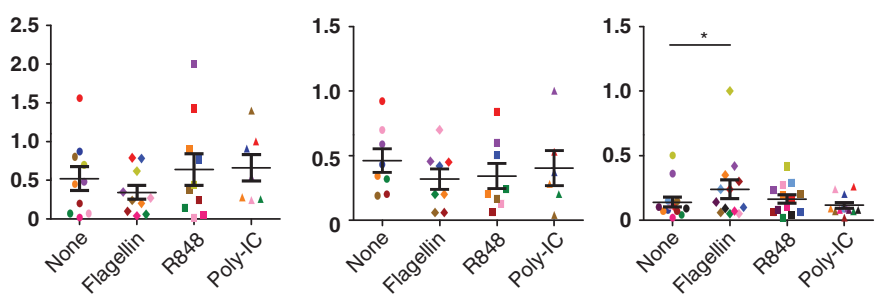

Figure 6 Vaginal Langerhans cells (LCs) and CD14- lamina propria-dendritic cells (LP-DCs) can efficiently induce interleukin (IL)-22-producing T-cell responses. 5,6-Carboxyfluorescein diacetate succinimidyl ester (CFSE)-labeled allogeneic naïve total T cells were cocultured for 7 days with the vaginal antigen-presenting cells (APCs) or DCs generated in the presence of interferon $\alpha$ (IFNDCs). T cells were restimulated with phorbol 12-myristate 13-acetate (PMA)/ionomycin in the presence of brefeldin A and then stained for intracellular IL-22. (a-d, $\mathbf{g})$ Data for CD4 ${ }^{+} \mathrm{T}_{\text {cells }}$ and $(\mathbf{e}, \mathbf{f}, \mathbf{h})$ data for $\mathrm{CD}^{+}{ }^{+}$T cells. (a) Representative data of one experiment are presented. (b, e) Summarized data from six independent experiments ${ }^{\star} P<0.05$; one-way analysis of variance (ANOVA) test). (c, d, f) Frequency of IFN $\gamma^{+}, \mathrm{IL}-5^{+}$, and IL-17 ${ }^{+}$cells among the IL-22-producing T cells. Five independent experiments using APCs from different donors showed similar results. (c) Representative data of one experiment after coculture with CD14 ${ }^{-}$LP-DCs or (d, f) combined data from five independent experiments using cells from different tissue donors. (g, h) Allogeneic naïve T cells were cocultured for 7 days with the vaginal APCs nonactivated or activated for $16 \mathrm{~h}$ with flagellin, R848, or poly-IC. T cells were then stained for intracellular IL-22 expression. Data from 7 (CD14 ${ }^{+}$LP-DCs) to 10 (macrophages $\left.(\mathrm{M} \phi)\right)$ independent experiments using APCs from different donors are presented $\left({ }^{\star} P<0.05\right.$; paired $t$-test). (b, e, $\left.\mathbf{g}, \mathbf{h}\right)$ Each color represents the data generated with one tissue donor.

inducing IL-21-producing $\mathrm{CD} 4^{+}$T-cell responses. Foremost, the magnitude of Th1 - vs. Th2-type responses can be balanced by distinct but compensatory functions of the individual APC subsets in a steady state. Microbial products and analogs bias the individual subset-driven immune responses. For example, activation of LCs and LP-DCs with R848 resulted in decreased $\mathrm{T}$-cell responses, particularly IL-5-producing T-cell responses. In contrast, R848 enhanced LCs and CD14 ${ }^{-}$LP-DC induced $\mathrm{IL}-22{ }^{+} \mathrm{CD} 4{ }^{+} \mathrm{T}$-cell responses. None of the microbial products tested in this study was able to activate the four APC subsets to induce the same types of T-cell responses. Studies have shown that intravaginal administration of vaccines can induce certain levels of protective immunity in both animals ${ }^{41-43}$ and humans. ${ }^{44-46}$ However, the development of safe vaccines that can establish protective mucosal immunity, particularly cellular immunity, which is crucial for the protection against intracellular pathogens, in the human vagina still remains as a challenge. ${ }^{1,3-5}$ Data from this study suggest that vaccines targeting proper vaginal APC subsets with right adjuvants could overcome this challenge.

Vaginal LCs and CD14 ${ }^{-}$LP-DCs can induce IL- $5^{+} \mathrm{CD} 8{ }^{+}$ $\mathrm{T}$ cells, which do not express IL-13. The physiologic function of 
$\mathrm{IL}-5^{+} \mathrm{CD} 8{ }^{+} \mathrm{T}$ cells is largely unknown, but $\mathrm{CD} 8^{+} \mathrm{T}$ cells in the genital tract are thought to be Tc2 or regulatory $\mathrm{T}$ cells. ${ }^{5,47}$ For the Th22, both LCs and CD14 ${ }^{-}$LP-DCs showed a similar ability to induce $\mathrm{IL}-22^{+} \mathrm{CD} 4{ }^{+}$and $\mathrm{IL}-22{ }^{+} \mathrm{CD} 8{ }^{+} \mathrm{T}$ cells expressing IFN $\gamma$ or IL-5, which is distinct from skin DCs and $\mathrm{IL}-22^{+} \mathrm{T}$ cells induced with skin DCs. ${ }^{38}$ To design more effective vaccines in the future, these features of the vaginal APCs also need to be considered.

$\alpha E \beta 7$ - (or CD103/ $\beta 7$-) integrin expressed on $\mathrm{T}$ cells ${ }^{26,27}$ allows lymphocytes to migrate into local mucosal tissues and contributes to their retention within the epithelial layers of the mucosa ${ }^{28}$ especially in the vagina. ${ }^{27,29}$ We demonstrate that fractions of T cells in the human vagina express CD103, CCR4, CXCR3, and $\beta 7$-integrin. More importantly, vaginal DCs, particularly LCs and CD14 ${ }^{-}$LP-DCs, can efficiently induce CD103 expression on both $\mathrm{CD}^{+}$and $\mathrm{CD}^{+}{ }^{+} \mathrm{T}$ cells. All subsets of vaginal APCs are able to induce similar levels of $\beta 7$-integrin and $\mathrm{CXCR}^{30}$ on T cells. Similarly, APCs from the vagina could induce CCR4, a chemokine receptor expressed on Th2-type $\mathrm{T}$ cells, on both $\mathrm{CD} 4^{+}$and $\mathrm{CD} 8^{+} \mathrm{T}$ cells. The numbers of CCR $4^{+} \mathrm{CD} 4^{+} \mathrm{T}$ cells induced by LCs or $\mathrm{CD} 14^{-}$ LP-DCs were higher than those induced by CD $14^{+}$LP-DCs or $\mathrm{M} \phi$. This is consistent with their capacity for polarizing T-cell responses toward Th2-type. Taken together, our data support that vaginal APC subsets have the unique capacity to directing immune responses in the vagina by inducing the expression of receptors that could allow effector cells to migrate into the vaginal mucosa.

To get further insight of the immunology of human vagina, future studies need to be performed in humans or animals that have similar features that human vagina has. The microenvironments in the vagina of humans and mice are different. First, the two are constantly exposed with different types of antigens. Second, commensal microorganisms in the two are not the same. Thus, APCs localized in the two immune systems could display distinct functions in directing the immune responses in the vaginal mucosa. This can be applied to the immune responses in a steady state as well as during microbial infections. Future studies also need to consider the effects of female hormones. ${ }^{48-50}$

In conclusion, human vaginal mucosa contains four major subsets of myeloid-derived APCs. Each of the subsets displays common as well as unique phenotypes and functions that direct the immune responses in the vagina. Such functional specialties and plasticity driven by the different subsets of the vaginal APCs may have important roles in shaping the vaginal mucosa as an immunologically unique microenvironment. To elicit desired types of adaptive immune responses in the vagina, antigens need to be delivered to the selected APC subset with adjuvants that can further promote the APC-mediated immune responses.

\section{METHODS}

Tissue samples. Vaginal tissues were obtained from patients (32-88 years old) who underwent pelvic or cosmetic surgeries under a protocol approved by the Institutional Review Board of Baylor
Research Institute (BRI). Patients were not infected with HIV, HCV, or $\mathrm{TB}$ and did not have inflammation. No other diagnosis information was available.

Enzymatic digestion of vaginal mucosa. Tissues were dissected free from fat, cut in small pieces $\left(1-5 \mathrm{~mm}^{2}\right)$, and digested for $3 \mathrm{~h}$ at $37^{\circ} \mathrm{C}$ with $0.6 \mathrm{U} \mathrm{ml}^{-1}$ Dispase II, $2 \mathrm{mg} \mathrm{ml}^{-1}$ collagenase D (Roche Applied Science, Indianapolis, IN), $200 \mu \mathrm{g} \mathrm{ml}^{-1}$ DNase I (Invitrogen, Carlsbad, CA), $20 \mathrm{U} \mathrm{ml}^{-1}$ hyaluronidase (Sigma Aldrich, St Louis, MO) in RPMI 1640 (Invitrogen) supplemented with $25 \mathrm{~mm} 4-(2-$ hydroxyethyl)-1-piperazineethanesulfonic acid buffer (Invitrogen), 2 mm L-glutamine (Sigma), 1\% nonessential amino acids (Sigma), 1 mm sodium pyruvate (Sigma), antibiotic/antimycotic (Invitrogen), and $5 \%$ fetal calf serum (HyClone, Logan, UT). Cell suspensions were filtered consecutively on 100,70 , and $40 \mu \mathrm{m}$ cell strainers (BD Biosciences, San Jose, CA) and washed.

Cell phenotypes and morphology. Cell phenotypes were assessed by flow cytometry analysis. Cells were stained with the following Abs and 7-aminoactinomycin D: anti-HLA-DR-AF700, anti-CD1c-AF647, anti-CD1a, anti-CD11c, anti-CD34, anti-CD54, anti-CD83, antiCD86, anti-CCR6, and anti-E-cadherin from BioLegend (San Diego $\mathrm{CA}$ ); anti-Langerin phycoerythrin (PE) from Beckman Coulter (Brea, CA); anti-Langerin AF488 (in-house); anti-CD14-eFluor450 (eBiocience, San Diego, CA); anti-CD66, anti-CD123, and anti- $\beta 7$ integrin Abs from BD Biosciences; anti-E/P selectin, anti-CCR2, anti-CCR4, anti-CCR5, anti-CCR7, and anti-CXCR4 Abs from R\&D Systems (Minneapolis, MN); anti-CD163 from BMA Biomedicals (Augst, Switzerland); and anti-CX3CR1 from MBL International (Woburn, MA). Phenotypes of vaginal APCs were analyzed by flow cytometry on an LSR II (BD Biosciences). Anti-CD103 and anti-CCR4 Abs used for T-cell phenotyping were from eBioscience and R\&D Systems, respectively.

Cell morphology was examined after the Giemsa staining of sorted vaginal APC subsets. Giemsa staining of sorted vaginal APCs was carried out using the Diff-Quik Stain Set according to the manufacturer's protocol (Siemens Healthcare Diagnostics, Erlangen, Germany). Images were acquired using an Olympus BX60 microscope (Olympus, Centre Valley, PA) with Planapo $100 \times / 1.4$ oil objective and a Nikon DXM1200C digital color camera (Nikon Instruments Inc., Melville, NY) with Nikon NIS Elements F Version 2.30 software (Nikon Instruments Inc.).

APC isolation. Tissues were cut into small pieces approximately $1 \mathrm{~cm}^{2}$, and incubated in phosphate-buffered saline containing $2 \mathrm{~mm}$ ethylenediaminetetraacetic acid and antibiotic/antimycotic solution overnight at $4{ }^{\circ} \mathrm{C}$. Epithelium and LP were then separated. LP was cut into smaller pieces $\left(1-5 \mathrm{~mm}^{2}\right)$. Epithelial sheets and LP pieces were incubated for 2 days at $37^{\circ} \mathrm{C}$ in RPMI 1640 supplemented with 4-(2hydroxyethyl)-1-piperazineethanesulfonic acid buffer, L-glutamine, nonessential amino acids, sodium pyruvate, antibiotic/antimycotic, and $10 \%$ fetal calf serum. Migratory cells were recovered, filtered consecutively on 100, 70, and $40 \mu \mathrm{m}$ cell strainers and washed. Cells were stained with 7 -aminoactinomycin D, anti-HLA-DR-AF700, antiLangerin-PE, anti-CD1c-FITC (Invitrogen), and CD14-eFluor450. $\mathrm{HLA}_{-\mathrm{DR}}{ }^{+}$cells were gated and then Langerin ${ }^{+}, \mathrm{CD}_{1}{ }^{+} \mathrm{CD} 14^{-}$, $\mathrm{CD} \mathrm{c}^{+} \mathrm{CD}_{14}{ }^{+}$, and CD $14^{+} \mathrm{CD} 1 \mathrm{c}^{-}$cells were sorted by FACS Aria II (BD Biosciences).

Preparation of T cells and monocyte-derived IFNDCs. Peripheral blood mononuclear cells from healthy volunteers were fractionated by elutriation, under a protocol that has been approved by the Institutional Review Board of Baylor Research Institute. IFNDCs were generated by culturing monocytes in serum-free medium (Cellgenix, Freiburg im Breisgau, Germany) supplemented with granulocytemacrophage-colony-stimulating factor $\left(100 \mathrm{ng} \mathrm{ml}^{-1}\right)$ and IFN $\alpha$ $\left(500 \mathrm{U} \mathrm{ml}^{-1}\right.$ ) (IFNDCs). The medium was replenished with cytokines on day 1 for IFNDCs. IFN $\alpha$ and granulocyte-macrophage-colonystimulating factor were from the Pharmacy at Baylor University 


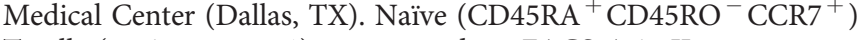
$\mathrm{T}$ cells (purity $>99.2 \%$ ) were sorted on FACS Aria II.

T-cell responses. A total of $1.5 \times 10^{5} \mathrm{CFSE}$-labeled purified naïve $\mathrm{T}$ cells were cocultured with $2 \times 10^{3}$ or the indicated number of APCs in RPMI 1640 supplemented with 4-(2-hydroxyethyl)-1-piperazineethanesulfonic acid buffer, L-glutamine, nonessential amino acids, sodium pyruvate, penicillin/streptomycin, and $10 \% \mathrm{AB}$ serum (GemCell, West Sacramento, CA). In some experiments, vaginal APCs were activated with R848 $\left(2 \mu \mathrm{g} \mathrm{ml}^{-1}\right)$, flagellin $\left(200 \mathrm{ng} \mathrm{ml}^{-1}\right)$, poly-IC $\left(2 \mu \mathrm{g} \mathrm{ml}^{-1}\right)$, or E. coli LPS $\left(100 \mathrm{ng} \mathrm{ml}^{-1}\right)$ for $16 \mathrm{~h}$ before the addition of T cells. All TLR-L are from Invivogen (San Diego, CA). After 7 days, cells were stained with anti-CD4 APC-Cy7 (BioLegend), anti-CD8 Pacific Blue (BioLegend) and LIVE/DEAD Fixable Dead Cell Stain Kit (Invitrogen), and T-cell proliferation was tested by measuring CFSE dilution. For cytokine expression analysis, $\mathrm{T}$ cells were restimulated with $100 \mathrm{ng} \mathrm{ml}^{-1}$ phorbol 12-myristate 13 -acetate (Sigma) and $1 \mu \mathrm{g} \mathrm{ml}^{-1}$ ionomycin (Sigma) for $6 \mathrm{~h}$ in the presence of GolgiPlug (BD Biosciences). They were then stained with anti-CD4, anti-CD8, LIVE/ DEAD Fixable Dead Cell Stain Kit, and anti-IFN $\gamma$, anti-IL-5, antiTNF $\alpha$, anti-IL-13 Abs (all from BioLegend), anti-IL-17, anti-IL-21, and anti-IL-22 Abs (all from eBioscience). Intracellular staining was performed using BD Cytofix/Cytoperm Fixation/Permeabilization Solution Kit (BD Biosciences) according to the manufacturer's protocol.

Immunofluorescence. Cryosections were fixed in cold acetone, dried, and blocked for nonspecific fluorescence with Fc receptor block and background buster (Innovex Biosciences, Richmond, CA). Sections were stained with the indicated Abs and then subsequently stained with 4',6-diamidino-2-phenylindole (Invitrogen). Digital images were taken using an Olympus BX51 with a Planapo20/0.7 or Planapo40/0.95 objective, a Roper Coolsnap HQ camera (Olympus) and Metamorph software (Molecular Devices, Sunnyvale, CA). FACS-sorted HLA$\mathrm{DR}^{+} \mathrm{CD}_{207}^{-} \mathrm{CD}^{-} \mathrm{C}^{-} \mathrm{CD} 14^{-}$cells were fixed in $4 \%$ paraformaldehyde and stained with the indicated Abs, and then subsequently stained with 4',6-diamidino-2-phenylindole. Confocal images were taken with the Leica SP1 (Leica, Buffalo Grove, IL) and Planapo63/1.32 objective. Images were acquired using the same exposures for $\mathrm{Ab}$ and isotype staining and identical scaling was applied.

Microarray analysis. RNA was purified following the manufacturer's instructions for the ArrayPure Nano-scale RNA Purification Kit (Epicentre Biotechnologies, Madison, VI). Amplification and labeling was carried out following the manufacturer's instructions for the TargetAmp 2-Round Biotin-aRNA Amplification Kit 3.0 (Epicentre). A total of $750 \mathrm{ng}$ of cRNA was used for hybridization of technical duplicates onto the Illumina Human H12v4 BeadChip. Scanning of the BeadChip was carried out on the iScan (Illumina Inc., San Diego, CA) using the manufacturer's recommended settings. Microarray data were background subtracted and scaled as per the Illumina GenomeStudio V2011.1 GX1.9.0 User Guide. GeneSpring v.7.3 (Agilent Technology Inc, Santa Clara, CA) software was used for unsupervised analysis and data filtering (detection $P<0.01$ in at least two samples). For each sample, background-subtracted and scaled-intensity values for the probes representing the genes of interest were exported to Excel. Values $<10$ were converted to 10 , and then the intensity average was calculated for biological replicates.

Statistical analysis. Statistical significance was determined using the analysis of variance test or paired $t$-test using the Prism 5 software (GraphPad Software, La Jolla, CA). Significance was set at $P<0.05$.

SUPPLEMENTARY MATERIAL is linked to the online version of the paper at http://www.nature.com/mi

\section{ACKNOWLEDGEMENTS}

We thank the FACS Core, Cell Processing Core, and Imaging Core at BIIR and the OR staff at BUMC. We thank Dr Rossello-Urgell for analyzing microarray data. We thank Drs Harrod (BIIR), Jeannin (INSERM U892), Eichelberger (FDA), and Zurawski (BIIR) for reading this manuscript. We also thank Dr Ramsay for supporting this study. This study was funded by 1RC1Al087379-01 (NIH grant), U19 Al057234 (NIH grant), and by the Baylor Health Care System Foundation. DD and SO designed experiments, analyzed data, and wrote the manuscript. DD, JG, EA, SZ, and MD performed experiments. JB helped manuscript writing. MC, MB, and JS provided tissue samples.

\section{DISCLOSURE}

The authors declare no conflict of interest.

c) 2013 Society for Mucosal Immunology

\section{REFERENCES}

1. Mestecky, J., Moldoveanu, Z., Smith, P.D., Hel, Z. \& Alexander, R.C. Mucosal immunology of the genital and gastrointestinal tracts and HIV-1 infection. J. Reprod. Immunol. 83, 196-200 (2009).

2. Iwasaki, A. Antiviral immune responses in the genital tract: clues for vaccines. Nat. Rev. Immunol. 10, 699-711 (2010).

3. Mestecky, J., Moldoveanu, Z. \& Russell, M.W. Immunologic uniqueness of the genital tract: challenge for vaccine development. Am. J. Reprod. Immunol. 53, 208-214 (2005).

4. Russell, M.W. \& Mestecky, J. Tolerance and protection against infection in the genital tract. Immunol. Invest. 39, 500-525 (2010).

5. Russell, M.W. \& Mestecky, J. Humoral immune responses to microbial infections in the genital tract. Microbes Infect. 4, 667-677 (2002).

6. Steinman, R.M., Hawiger, D. \& Nussenzweig, M.C. Tolerogenic dendritic cells. Annu. Rev. Immunol. 21, 685-711 (2003).

7. Villadangos, J.A. \& Schnorrer, P. Intrinsic and cooperative antigenpresenting functions of dendritic-cell subsets in vivo. Nat. Rev. Immunol. 7, 543-555 (2007).

8. Pulendran, B., Palucka, K. \& Banchereau, J. Sensing pathogens and tuning immune responses. Science 293, 253-256 (2001).

9. lijima, N., Thompson, J.M. \& Iwasaki, A. Dendritic cells and macrophages in the genitourinary tract. Mucosal Immunol. 1, 451-459 (2008).

10. Parr, M.B., Kepple, L. \& Parr, E.L. Langerhans cells phagocytose vaginal epithelial cells undergoing apoptosis during the murine estrous cycle. Biol. Reprod. 45, 252-260 (1991).

11. lijima, N. et al. Dendritic cells and B cells maximize mucosal Th1 memory response to herpes simplex virus. J. Exp. Med. 205, 3041-3052 (2008).

12. Jameson, B. et al. Expression of DC-SIGN by dendritic cells of intestinal and genital mucosae in humans and rhesus macaques. J. Virol. 76, 18661875 (2002).

13. Hussain, L.A. et al. Expression and gene transcript of $F c$ receptors for lgG, HLA class II antigens and Langerhans cells in human cervico-vaginal epithelium. Clin. Exp. Immunol. 90, 530-538 (1992).

14. Hershberg, R.M. et al. Intestinal epithelial cells use two distinct pathways for HLA class II antigen processing. J. Clin. Invest. 100, 204-215 (1997).

15. Taflin, C. et al. Human endothelial cells generate Th17 and regulatory Tcells under inflammatory conditions. Proc. Natl. Acad. Sci. USA 108, $2891-$ 2896 (2011).

16. Blauvelt, A., Katz, S.I. \& Udey, M.C. Human Langerhans cells express E-cadherin. J. Invest. Dermatol. 104, 293-296 (1995).

17. Zaba, L.C., Fuentes-Duculan, J., Steinman, R.M., Krueger, J.G. \& Lowes, M.A. Normal human dermis contains distinct populations of CD11C + BDCA-1 + dendritic cells and CD163 + FXIIIA + macrophages. J. Clin. Invest. 117, 2517-2525 (2007).

18. Serbina, N.V., Jia, T., Hohl, T.M. \& Pamer, E.G. Monocyte-mediated defense against microbial pathogens. Annu. Rev. Immunol. 26, 421-452 (2008).

19. Hladik, F. et al. Initial events in establishing vaginal entry and infection by human immunodeficiency virus type-1. Immunity 26, 257-270 (2007).

20. Williams, I.R. Chemokine receptors and leukocyte trafficking in the mucosal immune system. Immunol. Res. 29, 283-292 (2004).

21. van de Veerdonk, F.L. et al. STAT1 mutations in autosomal dominant chronic mucocutaneous candidiasis. N. Engl. J. Med. 365, 54-61 (2011). 
22. Puel, A. et al. Chronic mucocutaneous candidiasis in humans with inborn errors of interleukin-17 immunity. Science 332, 65-68 (2011).

23. Ferwerda, B. et al. Human dectin-1 deficiency and mucocutaneous fungal infections. N. Engl. J. Med. 361, 1760-1767 (2009).

24. Mathers, A.R. et al. Differential capability of human cutaneous dendritic cell subsets to initiate Th17 responses. J. Immunol. 182, 921-933 (2009).

25. Klechevsky, E. et al. Functional Specializations of Human Epidermal Langerhans Cells and CD14(+) Dermal Dendritic Cells. Immunity 29, 497-510 (2008).

26. Hladik, F., Lentz, G., Delpit, E., McElroy, A. \& McElrath, M.J. Coexpression of CCR5 and IL-2 in human genital but not blood T cells: implications for the ontogeny of the CCR5 + Th1 phenotype. J. Immunol. 163, 2306-2313 (1999).

27. Stevceva, L. et al. Cervicovaginal lamina propria lymphocytes: phenotypic characterization and their importance in cytotoxic T-lymphocyte responses to simian immunodeficiency virus SIVmac251. J. Virol. 76, 9-18 (2002).

28. Schon, M.P. et al. Mucosal T lymphocyte numbers are selectively reduced in integrin alpha E (CD103)-deficient mice. J. Immunol. 162, 6641-6649 (1999).

29. Csencsits, K.L., Walters, N. \& Pascual, D.W. Cutting edge: dichotomy of homing receptor dependence by mucosal effector B cells: alpha(E) vs. L-selectin. J. Immunol. 167, 2441-2445 (2001).

30. Nakanishi, Y., Lu, B., Gerard, C. \& Iwasaki, A. CD8(+) T lymphocyte mobilization to virus-infected tissue requires CD4 $(+)$ T-cell help. Nature 462, 510-513 (2009).

31. Kato, $H$. et al. Differential roles of MDA5 and RIG-I helicases in the recognition of RNA viruses. Nature 441, 101-105 (2006).

32. Yoneyama, M. et al. The RNA helicase RIG-I has an essential function in double-stranded RNA-induced innate antiviral responses. Nat. Immunol. 5, 730-737 (2004).

33. Wagner, T.L. et al. Modulation of $\mathrm{TH} 1$ and $\mathrm{TH} 2$ cytokine production with the immune response modifiers, R-848 and imiquimod. Cell Immunol. 191, 10-19 (1999).

34. Kolls, J.K., McCray, P.B. Jr. \& Chan, Y.R. Cytokine-mediated regulation of antimicrobial proteins. Nat. Rev. Immunol. 8, 829-835 (2008).

35. Ouyang, W. \& Valdez, P. IL-22 in mucosal immunity. Mucosal Immunol. 1, 335-338 (2008).

36. Malmberg, K.J. \& Ljunggren, H.G. Spotlight on IL-22-producing NK cell receptor-expressing mucosal lymphocytes. Nat. Immunol. 10, 11-12 (2009).

37. Vivier, E., Spits, H. \& Cupedo, T. Interleukin-22-producing innate immune cells: new players in mucosal immunity and tissue repair? Nat. Rev. Immunol. 9, 229-234 (2009)

38. Fujita, H., Nograles, K.E., Kikuchi, T., Gonzalez, J., Carucci, J.A. \& Krueger, J.G. Human Langerhans cells induce distinct IL-22-producing CD4 + T cells lacking IL-17 production. Proc. Natl. Acad. Sci. USA 106, 21795-21800 (2009).

39. Furio, L., Briotet, I., Journeaux, A., Billard, H. \& Peguet-Navarro, J. Human langerhans cells are more efficient than CD14 $(-) \mathrm{CD} 1 \mathrm{c}(+)$ dermal dendritic cells at priming naive $\mathrm{CD} 4(+) \mathrm{T}$ cells. J. Invest. Dermatol. 130, 1345-1354 (2010).

40. Rimoldi, M. et al. Intestinal immune homeostasis is regulated by the crosstalk between epithelial cells and dendritic cells. Nat. Immunol. 6, 507-514 (2005).

41. Parr, E.L. \& Parr, M.B. Immune responses and protection against vaginal infection after nasal or vaginal immunization with attenuated herpes simplex virus type-2. Immunology 98, 639-645 (1999).

42. Gillgrass, A.E., Tang, V.A., Towarnicki, K.M., Rosenthal, K.L. \& Kaushic, C. Protection against genital herpes infection in mice immunized under different hormonal conditions correlates with induction of vaginaassociated lymphoid tissue. J. Virol. 79, 3117-3126 (2005).

43. Wu, H.Y., Abdu, S., Stinson, D. \& Russell, M.W. Generation of female genital tract antibody responses by local or central (common) mucosal immunization. Infect. Immun. 68, 5539-5545 (2000).

44. Ogra, P.L. \& Ogra, S.S. Local antibody response to poliovaccine in the human female genital tract. J. Immunol. 110, 1307-1311 (1973).

45. Kozlowski, P.A. et al. Differential induction of mucosal and systemic antibody responses in women after nasal, rectal, or vaginal immunization: influence of the menstrual cycle. J. Immunol. 169, 566-574 (2002).

46. Kozlowski, P.A., Cu-Uvin, S., Neutra, M.R. \& Flanigan, T.P. Comparison of the oral, rectal, and vaginal immunization routes for induction of antibodies in rectal and genital tract secretions of women. Infect. Immun. 65, 1387-1394 (1997).

47. Nelson, M.H. et al. Rapid clearance of herpes simplex virus type 2 by CD8 + T cells requires high level expression of effector T cell functions. J. Reprod. Immunol. 89, 10-17 (2011).

48. Kaushic, C., Zhou, F., Murdin, A.D. \& Wira, C.R. Effects of estradiol and progesterone on susceptibility and early immune responses to Chlamydia trachomatis infection in the female reproductive tract. Infect. Immun. 68, 4207-4216 (2000)

49. Prieto, G.A. \& Rosenstein, Y. Oestradiol potentiates the suppressive function of human CD4 CD25 regulatory $T$ cells by promoting their proliferation. Immunology 118, 58-65 (2006).

50. Wira, C.R., Roche, M.A. \& Rossoll, R.M. Antigen presentation by vaginal cells: role of TGFbeta as a mediator of estradiol inhibition of antigen presentation. Endocrinology 143, 2872-2879 (2002). 